Illinois State University

ISU ReD: Research and eData

Theses and Dissertations

$4-28-2014$

\title{
Spatial Variability Of Erosion Patterns Along The Eastern Margin Of The Rio Grande Rift
}

Lauren Hoffman

Illinois State University, Ilhoffm@ilstu.edu

Follow this and additional works at: https://ir.library.illinoisstate.edu/etd

Part of the Hydrology Commons

\section{Recommended Citation}

Hoffman, Lauren, "Spatial Variability Of Erosion Patterns Along The Eastern Margin Of The Rio Grande Rift" (2014). Theses and Dissertations. 185.

https://ir.library.illinoisstate.edu/etd/185

This Thesis is brought to you for free and open access by ISU ReD: Research and eData. It has been accepted for inclusion in Theses and Dissertations by an authorized administrator of ISU ReD: Research and eData. For more information, please contact ISUReD@ilstu.edu. 


\title{
SPATIAL VARIABILITY OF EROSION PATTERNS ALONG THE EASTERN MARGIN OF THE RIO GRANDE RIFT
}

\author{
Lauren L. Hoffman
}

61 Pages

August 2014

The actively spreading Rio Grande Rift influenced uplift and erosion in Southwest North America, however the timing and progression of these processes is not well constrained in some smaller mountain ranges of the region. The Guadalupe and Sacramento Mountains located along the eastern margin of the rift in southern New Mexico were studied to improve our understanding of landscape evolution related to rifting. To address landscape evolution and the influence of tectonics I analyzed spatial distributions of erosion for each mountains range. I identified knickpoints along five longitudinal stream profiles from five canyons (4 in the Guadalupe Mountains and 1 in the Sacramento Mountains). I then coupled knickpoint elevations with histogram data to understand where majority of erosion occurs throughout each canyon. Histogram data joined with geologic data allowed for understanding why knickpoints exist. I used apatite (U-Th)/He low temperature thermochronology (AHe) to understand the cooling history of each range by dating apatite gains picked from bedrock and stream sediment samples. I used ages determined from bedrock samples to calculate the distribution of ages throughout a canyon. Using random sample points generated in ArcGIS to represent a sediment sample collected at the mouth of a stream, I calculate the probability density 
function to assess the probability of ages found within a stream sediment sample. Results from knickpoint analysis revealed that all five canyons contained knickpoints. Histogram results showed that larger areas were prominent at higher elevations, with which the knickpoint locations did not correlate. Geologic distribution revealed that knickpoints occur within resistant rock units (e.g. limestone). Bedrock grain analysis showed that apatite ages were reset and displayed ages between $24.9-28.3 \mathrm{Ma} \pm 5 \mathrm{Ma}$ which is similar to when rift propagation began $\sim 30 \mathrm{Ma}$ ago. Similarities in ages were also seen when comparing bedrock ages from this study to previous studies. For each sample location, it was found that $\sim 1.6 \mathrm{~km}$ was exhumed. Probability density function analysis revealed that the majority of ages found within a stream sediment sample would be found at higher elevations because of the distribution of carbonates. The quality of apatite was also addressed due to low helium concentrations in sediment samples. It was found that in order to have a high enough helium concentration, to assure accurate mineral identification, and to reduce uncertainty apatite grains picked must have a width greater than 70 um, must display a distinct crystal shape, and should not be rounded. Tying everything together, cooling histories determined from AHe analysis revealed that over the course of $30 \mathrm{Ma}$ approximately $1.6 \mathrm{~km}$ of sediment has been exhumed across the eastern margin. This coupled with knickpoint and histogram analyses proves that evolution of the landscape, especially along the Guadalupe and Sacramento Mountains, is influenced by regional rifting. 


\title{
SPATIAL VARIABILITY OF EROSION PATTERNS ALONG THE EASTERN MARGIN OF THE RIO GRANDE RIFT
}

\author{
LAUREN L. HOFFMAN
}

A Thesis Submitted in Partial

Fulfillment of the Requirements for the Degree of

MASTER OF SCIENCE

Department of Geography-Geology

ILLINOIS STATE UNIVERSITY 
(C) 2014 Lauren L. Hoffman 
SPATIAL VARIABILITY OF EROSION PATTERNS ALONG THE EASTERN MARGIN OF THE RIO GRANDE RIFT

LAUREN L. HOFFMAN

COMMITTEE MEMBERS:

Lisa Tranel, Chair

Dave H. Malone

Jonathan Thayn 


\section{ACKNOWLEDGMENTS}

From the beginning stages to the final draft I would like to thank my advisor Dr. Lisa Tranel whose persistence and knowledge of the project led to its completion. I want to thank my committee members Dr. Dave Malone and Dr. Jon Thayn for their time and willingness to help me through this process. I also want to thank Ms. Karen Dunton and my fellow graduate students for their unconditional support throughout my time at ISU.

I would also like to thank Dr. Nelson Ham who assisted with my graduate program search and for being my "words of wisdom."

This thesis is dedicated to my mother, Sue J. A. Hoffman, my father Joe M. Hoffman, and the rest of my family for believing in me every step of the way.

L.L.H. 


\section{CONTENTS}

ACKNOWLEDGEMENTS $\quad$ i

CONTENTS

TABLES $\quad$ iv

FIGURES $\quad$ V

EQUATIONS vii

\section{CHAPTER}

I. INTRODUCTION 1

Background 4

The Rio Grande Rift 4

The Guadalupe Mountains 6

The Sacramento Mountains $\quad 8$

$\begin{array}{ll}\text { Study Site } & 10\end{array}$

II. METHODOLOGY 12

Elevation Prediction Models $\quad 12$

(U-Th)/He Low Temperature Thermochronology 14

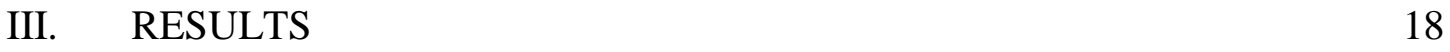

$\begin{array}{ll}\text { Predictions of Focused Erosion } & 18\end{array}$

Longitudinal Profiles $\quad 18$

Elevation Prediction $\quad 22$

Geologic Distribution 26

Apatite Cooling Ages $\quad 30$

Age - Elevation Gradient and Bedrock Age Distribution 35

Predicted Sediment Age Distribution 37

Apatite Size and Quality 39 
IV. DISCUSSION 41

Spatial Patterns of Erosion $\quad 41$

Timing of Exhumation 43

Apatite Quality $\quad 45$

V. CONCLUSIONS 47

$\begin{array}{ll}\text { REFERENCES } & 48\end{array}$

APPENDIX: Bedrock and Sediment Data 53 


\section{TABLES}

Table $\quad$ Page

1. Sample Information 30

2. Grain Data 39 


\section{FIGURES}

Figure $\quad$ Page

1. Regional map of the Rio Grande rift and surrounding areas 5

2. Stratigraphic column of the Guadalupe Mountains $\quad 7$

3. Stratigraphic column of the Sacramento Mountains 9

4. Study location map 11

5. Longitudinal profile of the North Rim, Guadalupe Mountains 19

6. Longitudinal profile of Devil's Den, Guadalupe Mountains 20

7. Longitudinal profile of Last Chance Canyon, Guadalupe $\begin{array}{ll}\text { Mountains } & 20\end{array}$

8. Longitudinal profile of Woods Canyon, Guadalupe Mountains 21

9. Longitudinal profile of Dog Canyon, Sacramento Mountains 21

10. Histogram of the North Rim, Guadalupe Mountains 23

11. Histogram of Devils Den, Guadalupe Mountains 23

12. Histogram of Last Chance Canyon, Guadalupe Mountains 24

13. Histogram of Woods Canyon, Guadalupe Mountains 24

14. Histogram of Dog Canyon, Sacramento Mountains 25

15. Geologic map of the North Rim, Guadalupe Mountains 27

16. Geologic map of Devils Den, Guadalupe Mountains 27

17. Geologic map of Last Chance Canyon, Guadalupe Mountains 28 
18. Geologic map of Woods Canyon, Guadalupe Mountains

23. Age - elevation graph for the North Rim, Guadalupe Mountains

24. Bedrock age distribution map of the North Rim, Guadalupe Mountains

25. Graph of the probability density function for the North Rim, Guadalupe Mountains

26. Graph of the change in uncertainty for the North Rim, Guadalupe Mountains 


\section{EQUATIONS}

Equation $\quad$ Page

1. Local Slope Calculation 13

2. Relative Ages Equation 16

3. Raster Calculation 16

4. Probability Density Function 17

5. Synoptic Probability Density Function 17 


\section{CHAPTER I}

\section{INTRODUCTION}

The Miocene to Holocene Rio Grande Rift is one of the major north-south tectonic features of North America's Cordillera. The Guadalupe and Sacramento Mountains of New Mexico lie along the Rift's eastern most edge and little is known about the exhumational and erosional history of these areas. Exhumation is the unroofing history or path of a rock toward the Earth's surface, due to denudational processes, where denudation is the removal of rock or soil by tectonic and/or surficial processes at a specific point at or under Earth's surface (Reiners and Brandon, 2006). Understanding how the landscape of both ranges is linked to rifting provides important information about the regional tectonic and geomorphic evolution.

Erosion shapes a landscape, and is influenced by tectonic processes. Spatially distributed changes in erosion may record evidence of regional tectonic processes. Throughout the history of a mountain range, rocks are eroded to form sediment. Sediment eroded through the canyon eventually makes its way to the mouth where it can be easily collected, used to spatially reconstruct the past (Stock et al, 2006), and used to understand erosional patterns. If enough sediment accumulates in adjacent basins, isostatic adjustment can occur (Pelletier, 2004). Knowing how much isostatic adjustment 
has occurred is determined by examining the slope of a canyon as well as analyzing stream incision patterns (Kirby and Whipple, 2001).

Active tectonics and uplift change the equilibrium of a system. It creates a feedback loop, by which tectonics increase erosion, erosion moves sediment, and sediment removal causes more uplift, and so the loop continues. The actual timing of exhumation due to uplift can be quantified using low temperature thermochronometry. The relative progression of uplift can be evaluated qualitatively by evaluating the shape and extent of erosional geomorphic features in the landscape.

To quantify when exhumation occurred, apatite (U-Th)/He low temperature thermochronology (AHe) was used to date recent cooling of bedrock samples from the two ranges. AHe measures the timing and rates at which rocks approach the surface and cool as a result of exhumation (Reiners and Brandon, 2006). AHe is a powerful approach to directly date the exhumational cooling of footwall rocks that accompanies normal fault slip in the crust during extension (Stockli, 2005). Footwall rocks moves upward during slip on a normal fault, leading to the exhumation and cooling of the footwall such that the timing of the fault slip can be estimated from the age of cooling (Stockli, 2005). This technique is most useful when dating geologic process in the upper part of the crust, such as rifts, orogeny, erosional exhumation, and landscape evolution. AHe dating involves relatively low temperatures of $\sim 80^{\circ} \mathrm{C}$ (Stockli, 2005; Wolf et al., 1998) and depths of approximately 1-3 km, which make it an ideal technique to use for this study (Stockli, 2005). It is hypothesized, that bedrock ages will return ages younger than Permian ages because if they were not reset, they would be older that Permian bedrock ages. I expect ages to be younger than the Permian and the same age as rifting 
because rifting is the most recent tectonic event and I expect that the rocks were buried deep enough to cause them to become reset. If rock units were not buried deep enough to reset ages then I expect ages to be older than Permian bedrock ages because sediments would have had to be eroded from pre-existing rock, transported, and deposited during the Permian. In addition to this, previous studies (Leonard, 2002; Reiter and Chamberlin, 2011) expect rifting to propagate northward. Therefore I expect to see older ages in the south and younger in the north.

To assess the influence of tectonics and spatial distributions of erosion for each mountain range I created longitudinal stream profiles to show at the location of knickpoints in each canyon. Knickpoints are associated with tectonic processes because they are formed from basement block faulting (Garner, 1983). Rock bodies are pushed up or exposed by faults to create scarps. In order for stream to acquire a more gentle slope they need to cut through rock bodies. Convexities along a stream profile represent the locations of knickpoints (Crosby and Whipple, 2006). Alternatively, knickpoints may reflect limited erosion due to highly resistant bedrock units (Foster and Kelsey, 2012). It is hypothesized that erosion will be prominent at knickpoint locations because of the exposure of fresh surfaces created by faulting and followed by knickpoint migration upstream to return the channel slope to equilibrium. Detrital apatite minerals were dated with AHe to try to trace sediments to their bedrock sources. Bedrock samples were used to extrapolate the bedrock ages across an entire catchment. Then ages in sediment samples could be compared to bedrock distributions to determine if focused erosion is occurring. If knickpoints instead reflect bedrock units of greater erosional resistance, I hypothesize that the resistant units might make up a greater portion of the elevation area. 


\section{Background}

\section{The Rio Grande Rift}

The Rio Grande Rift (figure 1) was recognized as an important continental rift during the 1970s and this feature has been the object of considerable study by geologists and geophysicists (Keller and Baldridge, 1999). The Rio Grande Rift separates the Great Plains to the east from the Colorado Plateau and Basin and Range province to the west. Development of the Rio Grande Rift started at about $30 \mathrm{Ma}$ (Barrow and Keller, 1994) with rapid extension oriented northeast-southeast producing northwest-southeast oriented basin structures characterized by normal faulting (Adams and Keller, 1994) A complexity associated with the rift is that it occurs in an area in which considerable Mesozoic and Cenozoic tectonic activity preceded rifting (Keller and Baldridge, 1999). The events associated with rifting include the Laramide compression or transpression, extensive Paleogene subduction-related volcanism, and finally extension. The basins of the Rio Grande rift are perhaps its most distinctive characteristic (Keller and Baldridge, 1999). The sediments filling these basins are well-exposed because of Neogene uplift and erosion, providing detailed information about the timing of events during the evolution of the rift (Keller and Baldridge, 1999). 


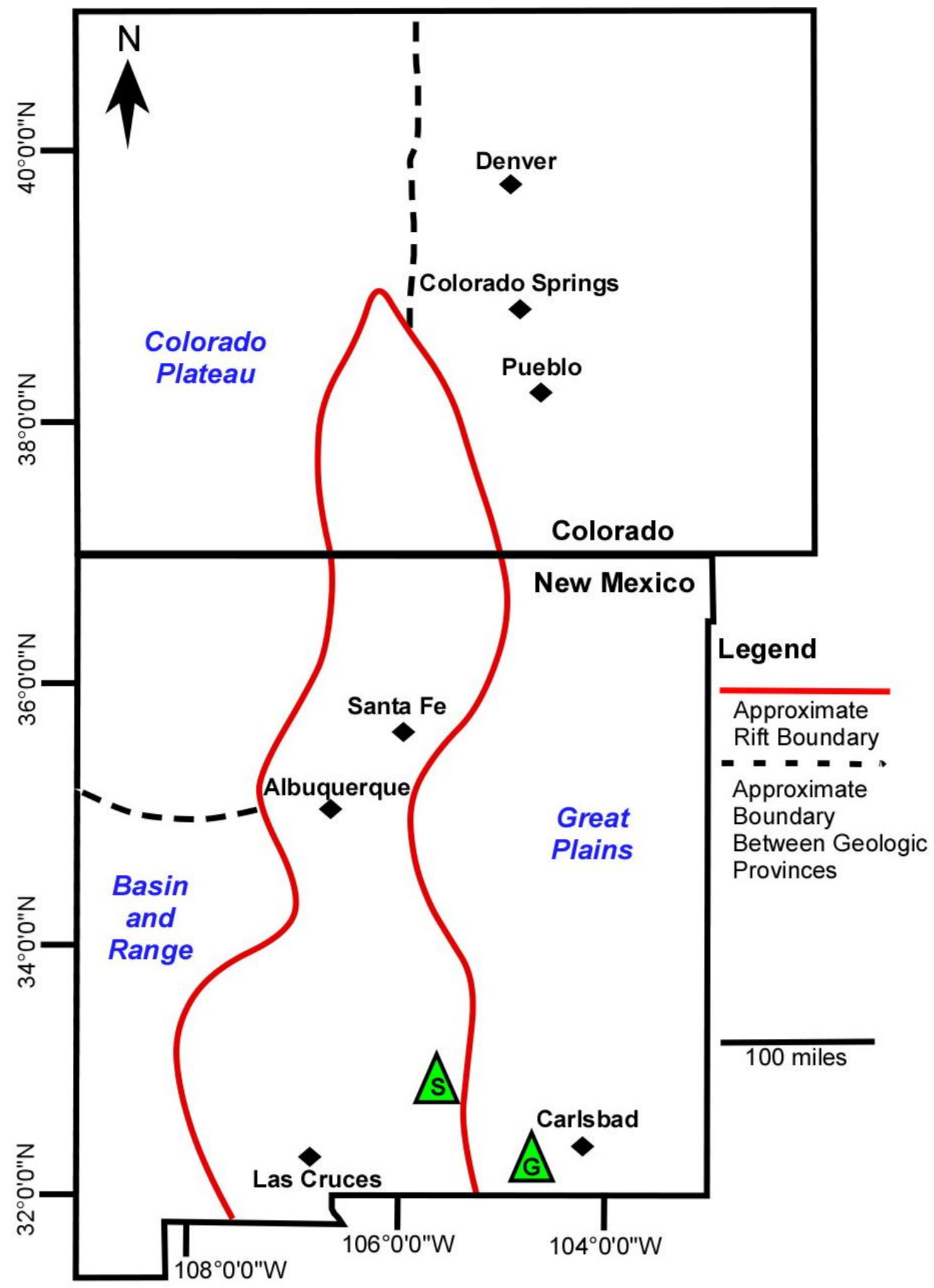

Figure 1: Regional map of the Rio Grande rift and surrounding areas. 


\section{The Guadalupe Mountains}

The Guadalupe Mountain Ranges of New Mexico and west Texas is a northeast tilted fault block ranging in elevation from $2667 \mathrm{~m}$ at Guadalupe Peak to $960 \mathrm{~m}$ near the city of Carlsbad. Faulting exhumed a portion of the Captain Reef Complex, a Permian shelf margin that rings the Delaware Basin (DuChene and Martinez, 2000). The range is located to the east of the Rio Grande rift. Faults along the west flank of the mountains trend parallel to the axis of the range and are either vertical or dip steeply to the west (King, 1984). Faults appear to be tensional features, caused by vertical acting motion, but the ultimate cause may have been compressional force (King, 1948). West of the Guadalupe Mountains is a graben drained by Big Dog and Upper Dog Canyons. This area is bounded on the west by a north-northwestward-trending zone of normal faults of late Cenozoic age in and adjacent to the Brokeoff Mountains (Hayes, 1964). Sedimentary rock formations that occur here are the Captain, Cherry Canyon, Brushy Canyon, and Bone Spring (figure 2). 


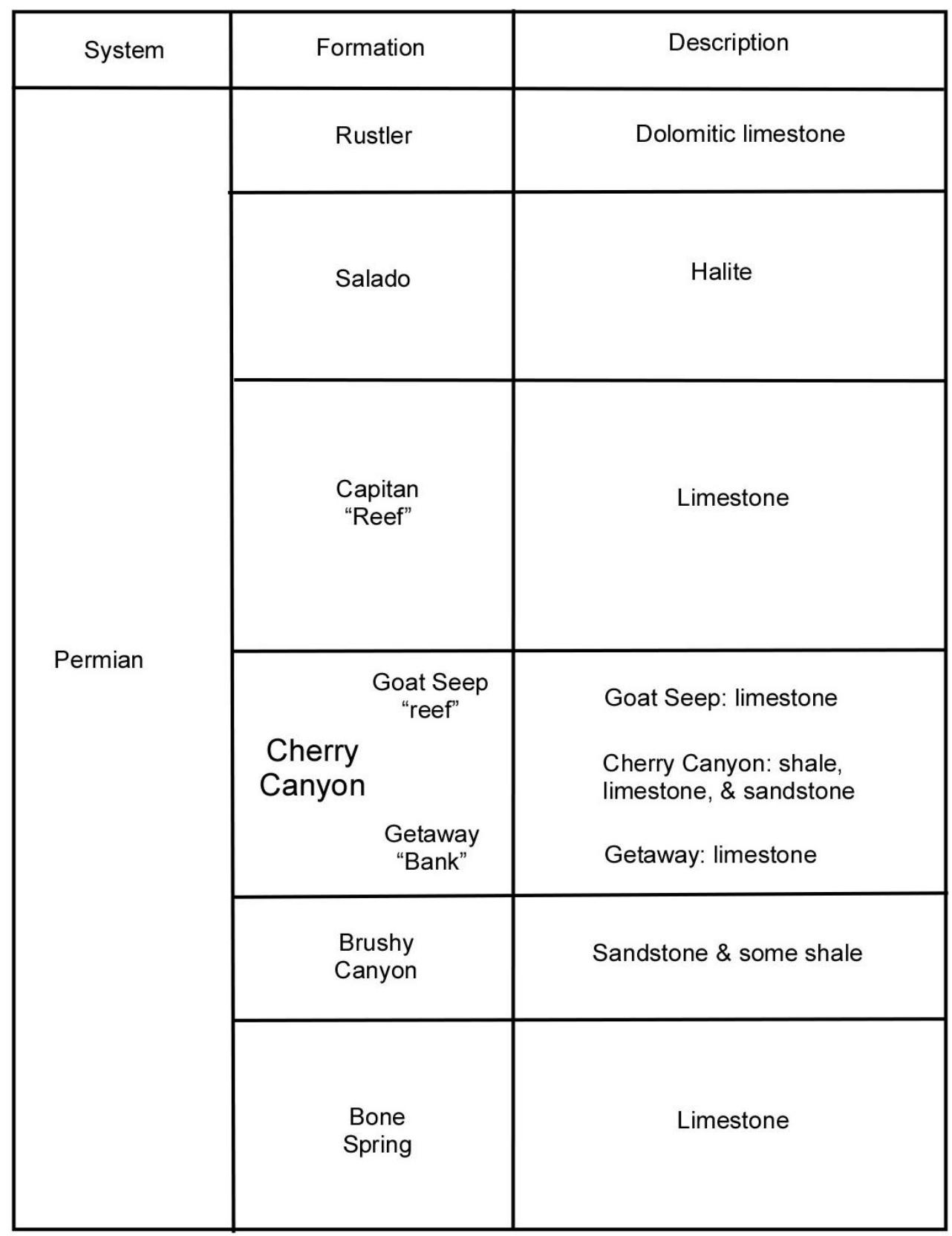

Source: Modified after King, 1948

Figure 2: Stratigraphic column of the Guadalupe Mountains. 


\section{The Sacramento Mountains}

The Sacramento Mountains constitute a sharp ridge at the eastern edge of the Basin and Range province in south-central New Mexico (Pray, 1961). The range is located to the north of the Guadalupe Mountains and is situated to the east of the Rio Grande rift. The Sacramento Mountains form an abrupt escarpment on the eastern side of the Tularosa Valley for a distance of $64 \mathrm{~km}$ (Pray, 1961). The Sacramento Mountains are interpreted to be the result of uplift with respect to the area of the Tularosa Valley along a normal fault that is at, or close to, the present base of the escarpment (Pray, 1961). The crest of the Sacramento Mountains forms a gentle arch which lies above an elevation of $2750 \mathrm{~m}$ for a distance of about twenty miles, and the highest elevation is about $3000 \mathrm{~m}$ (Pray, 1961). The strata of the range are Paleozoic in age. Formations located throughout the region (figure 3) are the Bliss Sandstone, Gobbler, Beeman, Holder, Bursum, Abo, Yeso, and the San Andres Limestone Formations (Pray, 1977). 


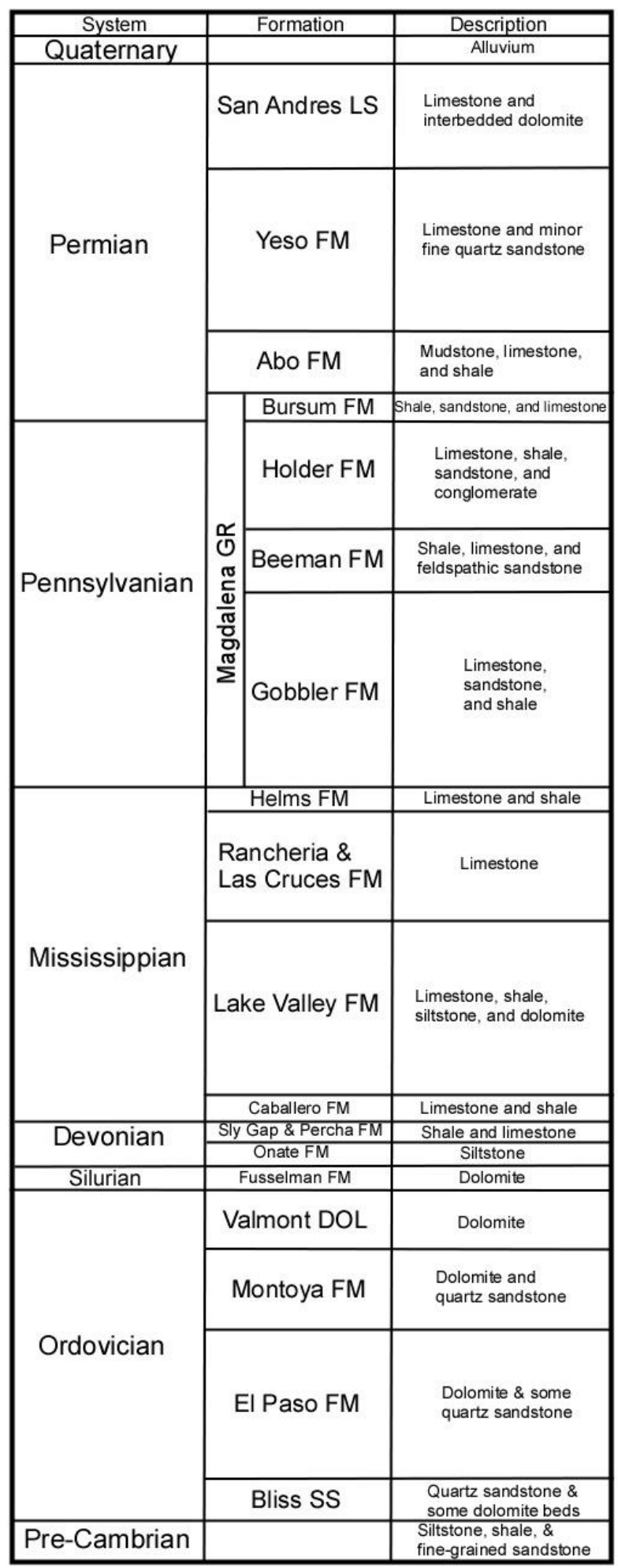

Source: Modified after Pray, 1954

Figure 3: Stratigraphic column of the Sacramento Mountains 


\section{Study Site}

This study focuses on the Rio Grande rift, a prominent North American tectonic feature that is actively spreading. Two mountains ranges, the Guadalupe and Sacramento Mountains, located in southern New Mexico were chosen as study sites because they exist along the eastern margin of the rift and few studies have been done to quantify when exhumation occurred. Five canyons were chosen for sample collection and for spatial distribution analysis. From the Guadalupe Mountains: the North Rim, Devils Den, Woods Canyon, and Last Chance Canyon. From the Sacramento Mountains: Dog Canyon. Figure 4 shows the location of each canyon and its associated mountain range.

The geologic units that comprise both mountains ranges consist of limestone, shale, dolomite and sandstone. Limestone was seen as the major cliff forming unit while sandstone was seen as the slope forming unit due to the low number of outcrops. Sandstone exists mainly as interbedded units within formations and because of it low resistivity it erodes quickly.

The climate is semiarid with average annual precipitation ranging from about $0.33 \mathrm{~m}$ in the lower elevation to $0.51 \mathrm{~m}$ at higher elevations (Hayes, 1964). Vegetation is sparse throughout the Guadalupe Mountains with thin juniper forests and scattered pines at higher elevations (Hayes, 1964). The Sacramento Mountains have slightly more vegetation with a pine forest existing at higher elevations. 


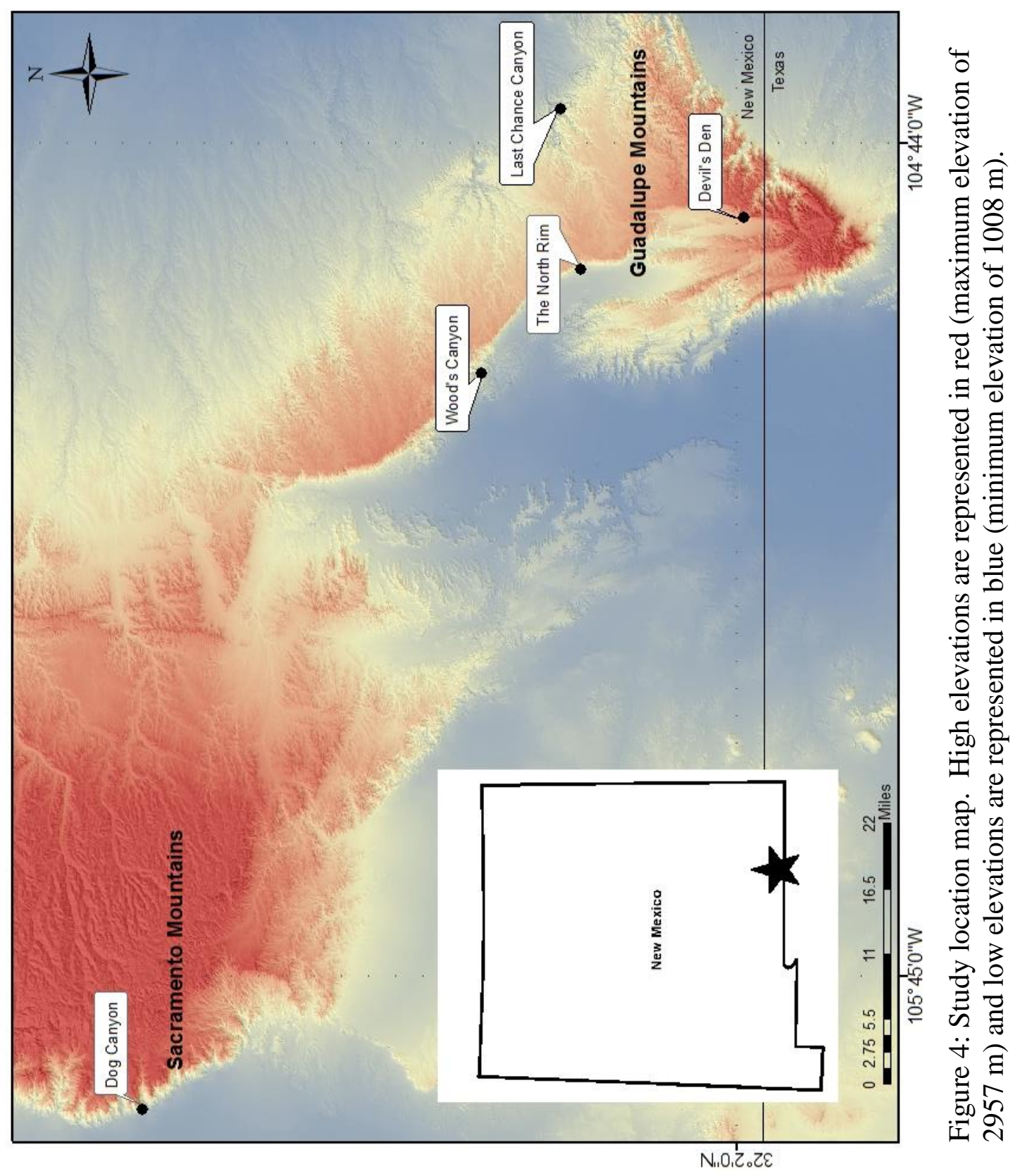




\section{CHAPTER II \\ METHODOLOGY}

\section{Elevation Prediction Models}

Spatial patterns of erosion can be easily evaluated even before entering the field using digital elevation models (DEM) to identify selected geomorphic features. I used ArcGIS, a geographic information system with valuable hydrology and three-dimensional tools to model and predict erosional patterns between the Guadalupe and Sacramento Mountains of New Mexico. Before predictions could be made a 30-m digital elevation model was downloaded from the New Mexico RGIS (Earth Data Analysis Center, 2004) and projected in North American Datum 1983 to match GPS coordinates. The DEM was manipulated to generate watersheds for each canyon. Sinks within the DEM were filled, flow accumulation was calculated, a raster calculation was done to extract streams as a raster, and stream link was used to create a new raster. From the stream link raster I determined pour point locations. Locations were picked downstream from sampling locations to ensure the entire canyon drainage network was included in the watershed calculations. Watersheds were calculated for every canyon and used to generate histograms and longitudinal profiles.

Identifying knickpoints along longitudinal profiles provides one way to predict areas of focused erosion. Longitudinal stream profiles represent the channel slope from the head waters to the mouth viewed in cross section. The profiles can be described as 
concave or convex. Concave features represent a system in equilibrium while convexities represent a change in the land surface, e.g. faults, or more resistant rock units (Seidl et al., 1994). Convexities are known as knickpoints which are assumed to be associated with increased rates of erosion (Garner, 1983). I generated longitudinal profiles in GIS (Cooley, 2014) and graphed them as distance from the beginning of the stream against elevation (figures 5-9). I identified knickpoints on each profile by noting convexities. Then I verified knickpoint locations using a local slope calculation (equation 1) and plotted next to elevation and cell count.

$$
L S=A b S\left[\frac{E_{1}-E_{2}}{D_{1}-D_{2}}\right]
$$

\section{Equation 1: Local Slope Calculation. Where: LS = Local Slope, $\mathrm{E}=$ Elevation, and $\mathrm{D}=$ Distance}

Spikes in the graph represent locations of knickpoints. Then I used ArcGIS to create histograms of elevation and percent area (figure 10-14).

Calculating the amount of area at specific elevations allows for understanding bedrock characteristics. Areas with steep slopes are assumed to erode faster (Montgomery and Brandon, 2002) due to mass wasting and runoff at higher elevations. Histograms are the visual representation used to display elevations against the percent area. Incorporating knickpoint data from profile analysis to histogram data aids with understanding why knickpoints exist at those specific elevations. I calculated histograms for each of the five canyons by using the Geostatistical Analyst Histogram tool in ArcGIS. 
Erosion along any surface is directly influenced by the geology. Resistant units such as limestone will erode at a much slower rate compared to sandstone which is a less resistant unit. Geology paired with knickpoint locations can predict if there will be focused erosion at knickpoint locations without having to visit each location. I manipulated histogram data by excluding all elevations, except knickpoint elevations, by using Reclassify from the Spatial Analyst toolbox. I overlaid the knickpoint elevations on top of the geologic maps that were extracted for each canyon's watershed (figures 1519).

\section{(U-Th)/He Low Temperature Thermochronology}

Apatite (U-Th)/He thermochronology (AHe) has become an important tool for understanding the cooling history of rocks as they pass through the upper 1-3 $\mathrm{km}$ of the crust (Ehlers and Farley, 2003). The low closure temperature of this decay series has gained the interest of geomorphologists because it is applicable to interdisciplinary studies in landform evolution, structural geology, and geodynamics (Ehlers and Farley, 2003). I used this method because the lower closure temperature of the apatite He system makes it possible to detect and quantify degrees of tectonically induced cooling that are too small to be recorded by higher temperature systems (Ehlers et al., 2001;Ehlers and Farley, 2003; Stockli, 2005).

In total, 23 samples were collected; I collected 18 new samples in March of 2013 and 5 were previously collected bedrock samples. I chose sample sites based on the availability of sandstone deposits (determined from Green and Jones (1997), The Digital Geologic Map of New Mexico) and on accessibility. Table 1 shows the location and type of sample collected. Of the 5 locations, I chose 2 catchments for this study due to time 
constraints: Dog Canyon (Sacramento Mountains) and the North Rim (Guadalupe Mountains).

I processed 10 samples for apatite analysis: 2 sediment samples and 8 bedrock samples. Processing involved crushing bedrock samples through a rock crusher and hand sieving crushed rock to separate $<250 \mu \mathrm{m}$ from $>250 \mu \mathrm{m}$ grains. The $<250 \mu \mathrm{m}$ sieved samples were then sent through the Wilfley Table to wash out silt and clay particles. Wet sediment was dried and a hand magnet was used to extract magnetic minerals. Next, 100 g of dried sediment was put into LST - heavy liquids (solution of lithium heteropolytungstates in water) to separate dense minerals (e.g. apatite) from less dense minerals (e.g. quartz). The sediment was dried again and then sent though the Frantz magnetic separator to remove remaining magnetic minerals. The non-magnetic fraction was then hand-picked under a microscope for individual apatite grains and loaded into platinum tubes.

I picked 14 to 31 grains for each bedrock sample depending on the amount of apatite available and divided then into 2-4 aliquots, each containing varying amounts of grains (see Appendix A for exact numbers). For sediment samples, I picked 20 individual apatite grains per sample and loaded them into individual tubes. I then loaded aliquots into platinum tubes, crimped them shut, labeled them, and sent them off to Virginia Tech and the University of Michigan for helium analysis, and to the University of Arizona for uranium and thorium chemistry. During picking I inspected each apatite grain and photographed them to make sure they were roughly the same size, shape, and free of inclusions or fractures, and to determine the amount of apatite per sample. I processed SM4 from the Sacramento Mountains but I did not send it out due to time constraints. 
SM1 and SM3 did not contain apatite so they were also not sent out for analysis.

GMLH1302 from the Guadalupe Mountains was sent out and I am currently waiting on an ages for that sample.

I plotted bedrock ages from the North Rim against sample elevations to derive the relative ages equation (2) to extrapolate cooling ages throughout the study area.

$$
x=\frac{(y+b)}{m}
$$

Equation 2: Relative Ages Equation. Where: $\mathrm{x}=$ age, $\mathrm{y}=$ elevation, $\mathrm{b}=$ slope, $\mathrm{m}=\mathrm{y}$-intercept

I then used equation 2 along with the North Rim elevation DEM in a raster calculation (equation 3) in GIS to calculate ages at each elevation for the canyon.

\section{("Elevation_DEM" + b) / m}

\section{Equation 3: Raster Calculation}

Ages were plotted within the watershed along with knickpoint locations allowing for knickpoint ages to be identified.

I did not use sediment ages because helium concentrations were too low. Instead, I used bedrock grain ages from the North Rim to generate fifty random sample points to represent the predicted distribution of erosion if all surfaces are eroding equally. I created random sample points with the Create Random Points tool in the Data Management toolbox. The random points represent a predicted distribution of sediment ages that would have been collected at the mouth of the canyon. I then calculated the 
probability density function (PDF; equation 4) from predicted ages, and the synoptic probability density function (SPDF; equation 5) from the PDF. The SPDF is defined as the sum of the PDFs for each mineral grain dated (predicted sample ages), with the area under the curve normalized to one (Ruhl and Hodges, 2005).

$$
P D F=\frac{1}{\sigma_{t_{m}} \sqrt{2 \pi}} \exp \left[-\frac{1}{2}\left(\frac{t-t m}{\sigma_{t_{m}}}\right)^{2}\right]
$$

Equation 4: Probability Density Function. Where $\sigma \mathrm{tm}=$ standard deviation, $\mathrm{tm}=$ random sample age (at $\%$ uncertainty), $\mathrm{t}=$ probability age (Ruhl and Hodges, 2005)

$$
S P D F=\frac{1}{n} \sum_{i=1}^{n} P D F(i)
$$

Equation 5: Synoptic Probability Density Function. Where PDF = probability density function and $\mathrm{n}=$ number random points (Ruhl and Hodges, 2005)

Lastly, I manipulated SPDFs to determine the importance of uncertainty by changing the percent uncertainty $(10 \%, 20 \%$, and $40 \%)$ which I calculated by taking the standard deviation of the actual sample ages divided it by the average age of the sample and then multiplied by a hundred. 


\section{CHAPTER III}

\section{RESULTS}

\section{Predictions of Focused Erosion}

\section{Longitudinal Profiles}

To identify knickpoints (convexities) in the field sites, I generated longitudinal profiles for each of the five canyons. Results from profile analysis alone showed that three of the five catchments contained knickpoints, however local slope calculations revealed that all five catchments contain knickpoints (figures 5-9). In the Guadalupe Mountains: The North Rim (1750 m and $1550 \mathrm{~m}$ ), Devils Den (2000 m and $1860 \mathrm{~m}$ ), and Woods Canyon (1700 m and $1450 \mathrm{~m}$ ) had two knickpoints each while Last Chance Canyon had one knickpoint at 1500 m. Dog Canyon, from the Sacramento Mountains, contained two knickpoints, an upper at $2000 \mathrm{~m}$ and a lower at $1550 \mathrm{~m}$.

Comparing knickpoint elevations along the western side of the Guadalupe Mountains, The North Rim (1550 m) and Woods Canyon (1450 m) knickpoints occur at nearly the same elevations (figures 5 and 8). Devils Den (figure 6) knickpoints were found to exist at the highest elevations along the western side of the Guadalupe Mountains with the lower knickpoint $(1850 \mathrm{~m})$ being similar to that of the North Rim's upper knickpoint (1750 m). Last Chance Canyon (figure 7), an eastern draining canyon 
of the Guadalupe Mountains, also has a knickpoint $(1500 \mathrm{~m})$ similar to that of the lower North Rim and Woods Canyon knickpoints. Dog Canyon (figure 9), from the Sacramento Mountains, has a lower knickpoint elevation $(1550 \mathrm{~m})$ similar to Woods Canyon (1450 m) and The North Rim (1550 m), and a higher knickpoint elevation (2000 m) similar to Devils Den (2000 m).

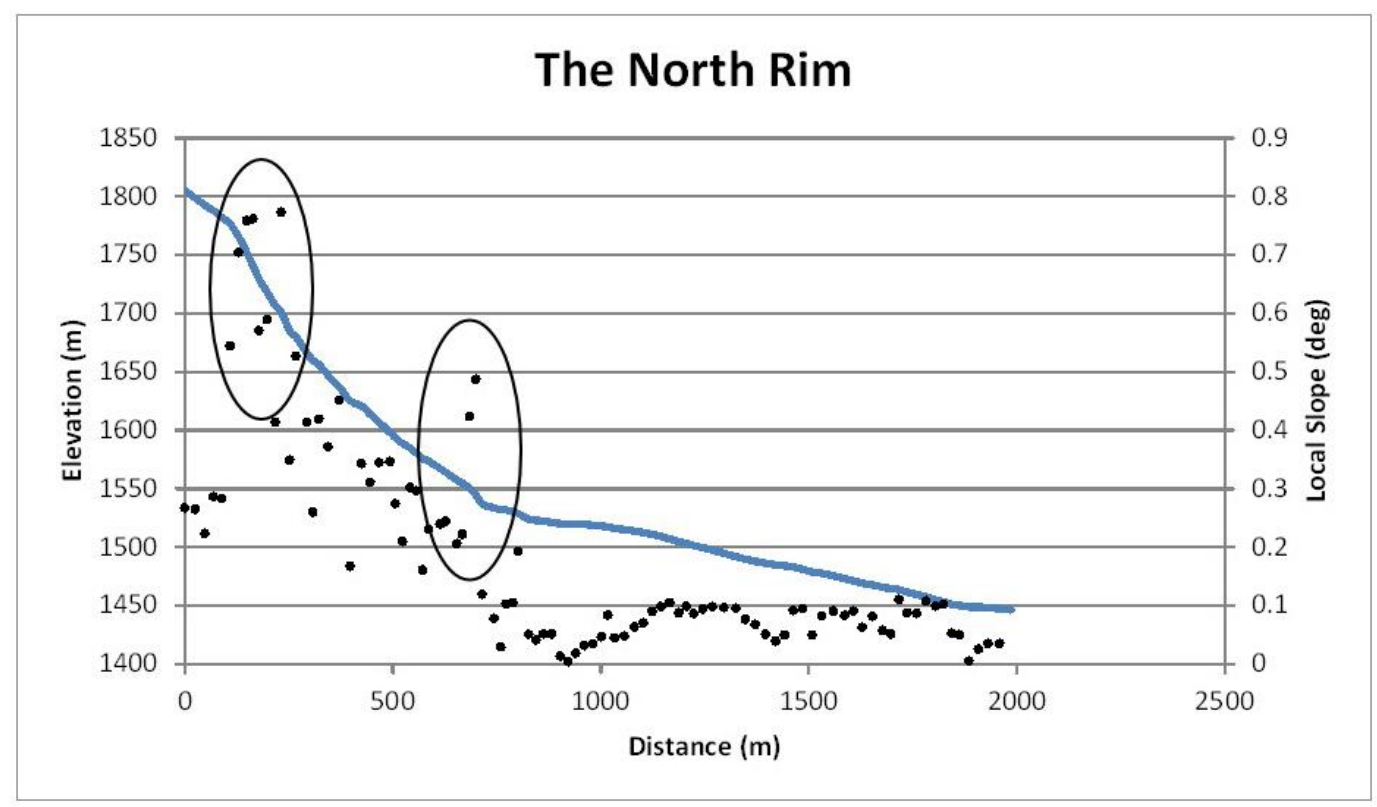

Figure 5: Longitudinal profile of the North Rim, Guadalupe Mountains. Dots represent local slope calculations. Circled areas are knickpoint locations. 


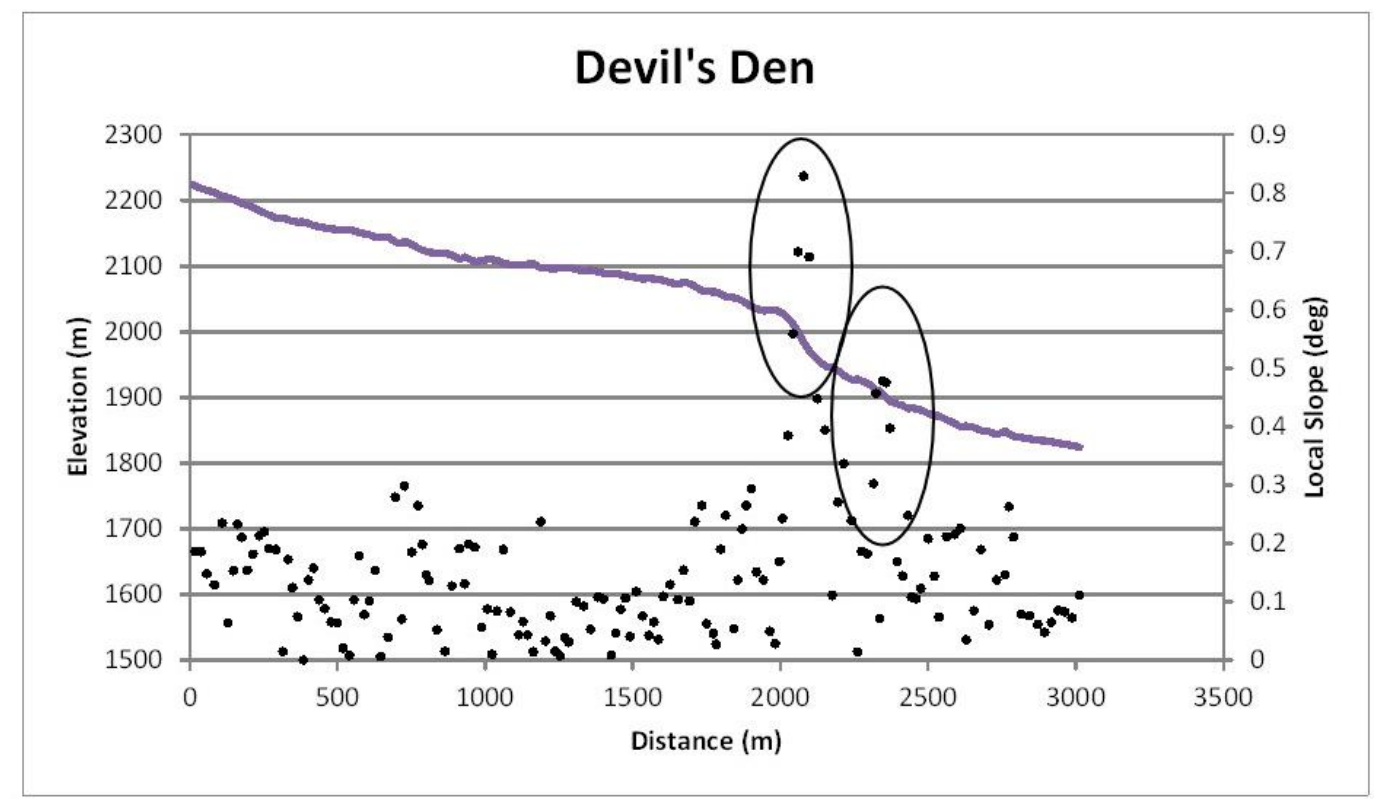

Figure 6: Longitudinal profile of Devil's Den, Guadalupe Mountains. Dots represent local slope calculations. Circled areas are knickpoint locations.

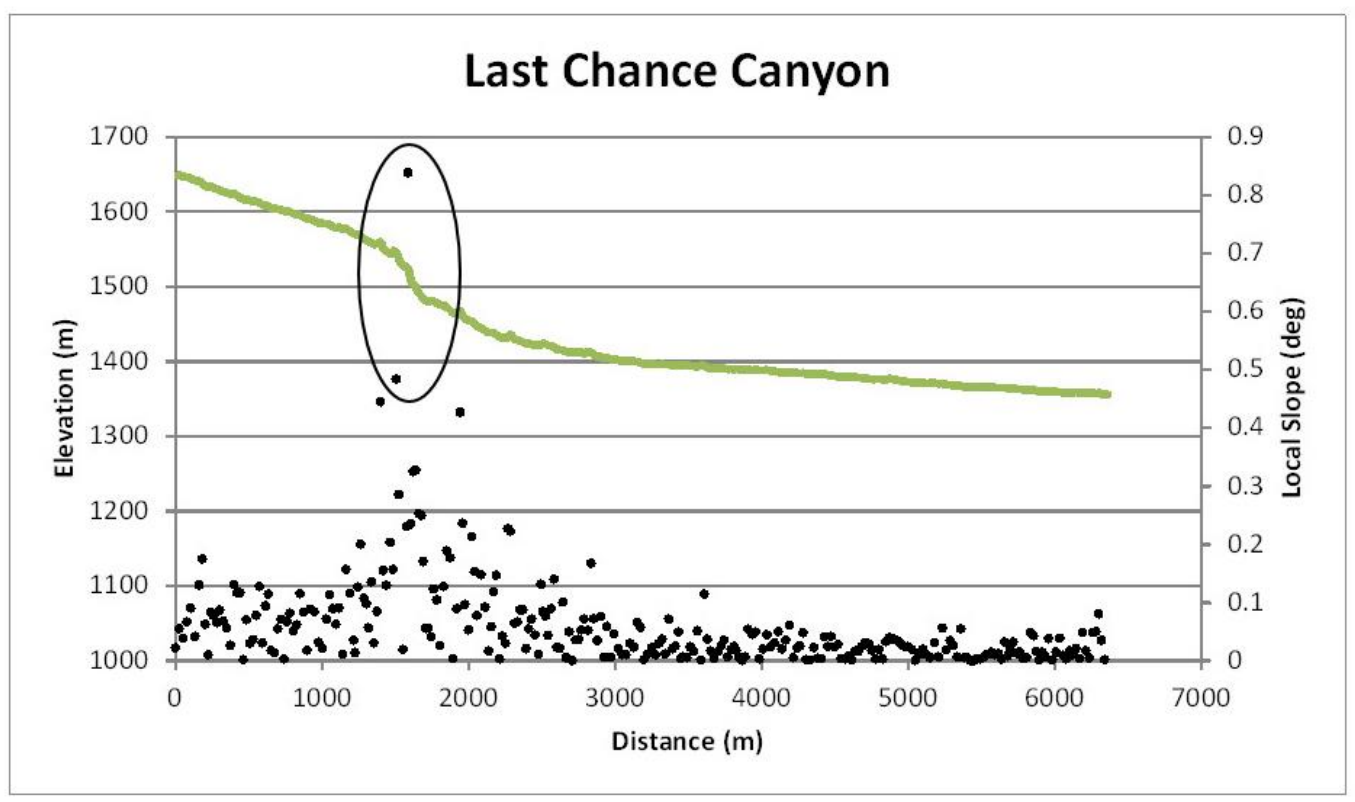

Figure 7: Longitudinal profile of Last Chance Canyon, Guadalupe Mountains. Dots represent local slope calculations. Circled areas are knickpoint locations. 


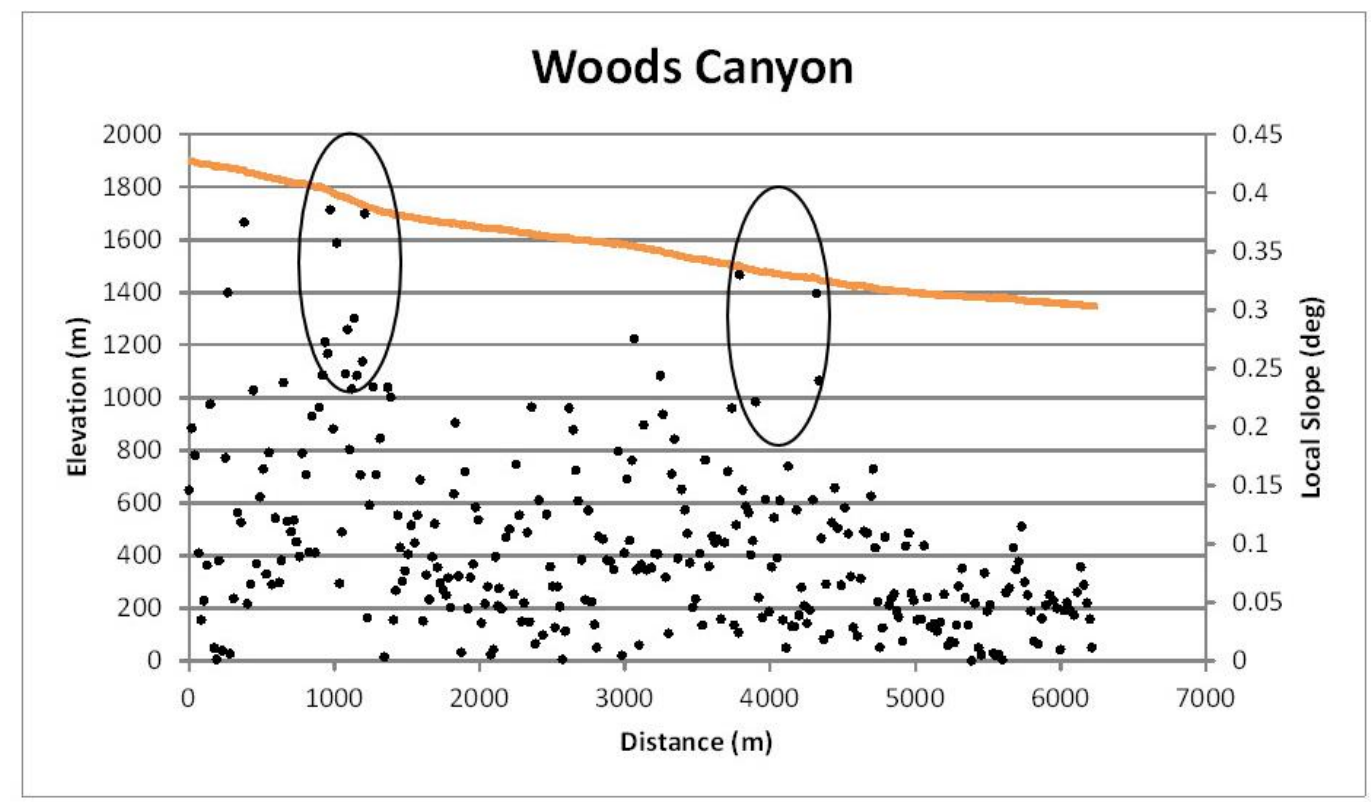

Figure 8: Longitudinal profile of Woods Canyon, Guadalupe Mountains. Dots represent local slope calculations. Circled areas are knickpoint locations.

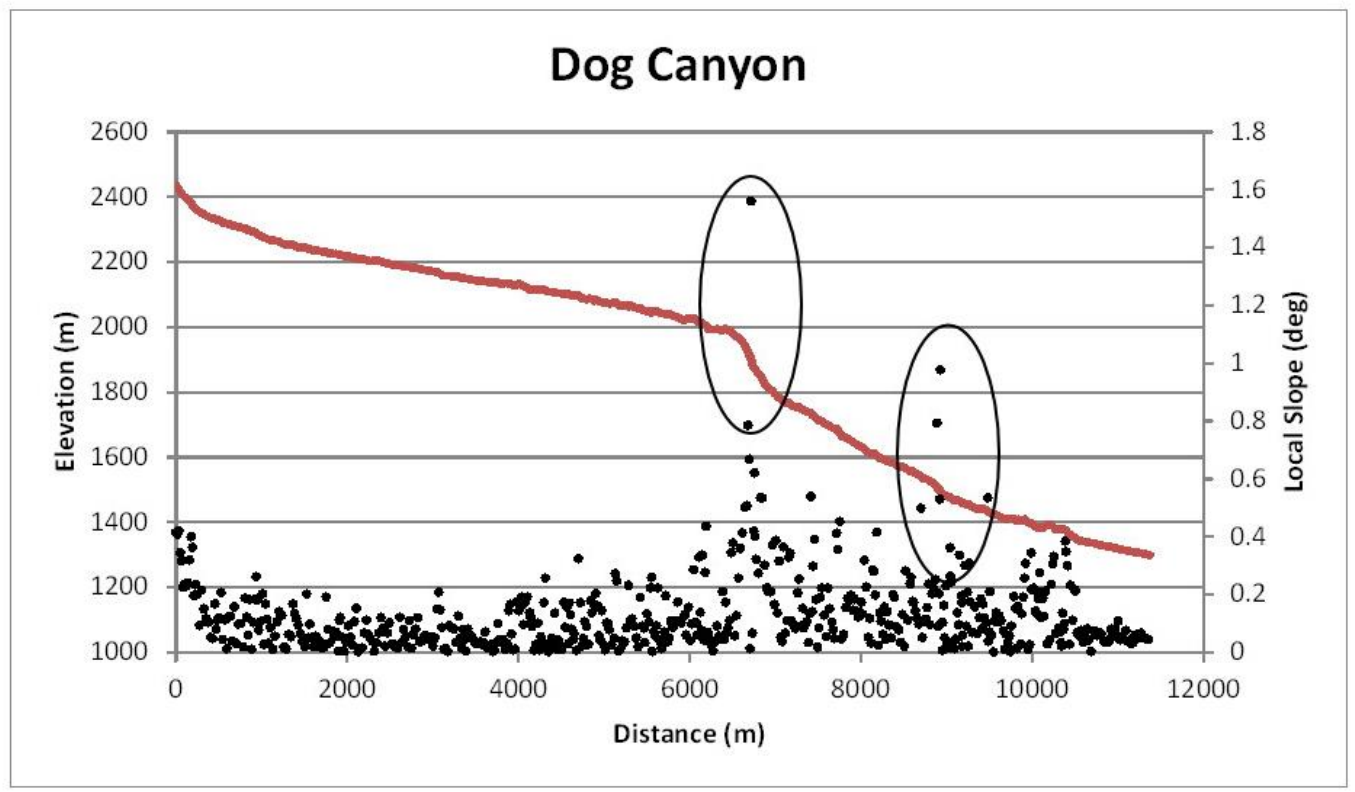

Figure 9: Longitudinal profile of Dog Canyon, Sacramento Mountains. Dots represent local slope calculations. Circled areas are knickpoint locations. 


\section{Elevation Prediction}

Another way to predict areas of erosional resistance is to understand at what elevation the majority of the area is at and creating a histogram is a way to display that relationship. Overlying knickpoint data from profile analysis on top of histograms aids with understanding why knickpoints exist at those specific elevations. Figures 10-14 show knickpoint elevations from longitudinal profiles with histogram data. I found that knickpoint elevations do not correlate with larger areas of elevation. In the Guadalupe Mountain's, the North Rim (figure 10) has a larger percent area associated with $~ 1800-$ 1900 m elevations, Devil's Den (figure 11) has a larger percent area associated with 2100-2250 m elevations, Last Chance Canyon (figure 12) has a larger percent area associated with 1600-1900 m elevations, and Wood's Canyon (figure 13) has a larger percent area associated with $\sim 1400 \mathrm{~m}, \sim 1650 \mathrm{~m}$, and $\sim 1880 \mathrm{~m}$. In the Sacramento's, Dog Canyon (figure 14) has a larger percent area with 2100 - 2400 m elevations. These elevations do not coincide with profile knickpoint elevations and could be due to more resistive rock units. 


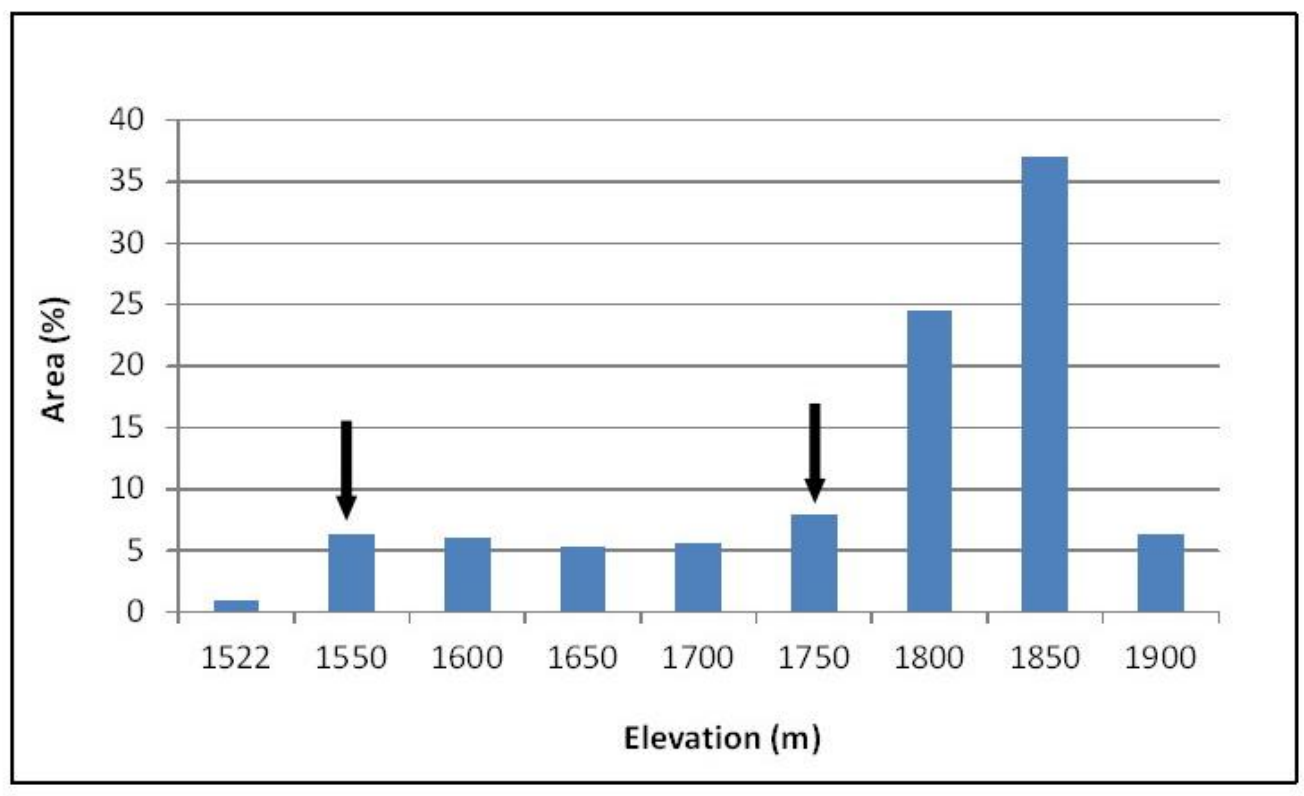

Figure 10: Histogram of the North Rim, Guadalupe Mountains. Arrows represent locations of knickpoints identified from profile analysis.

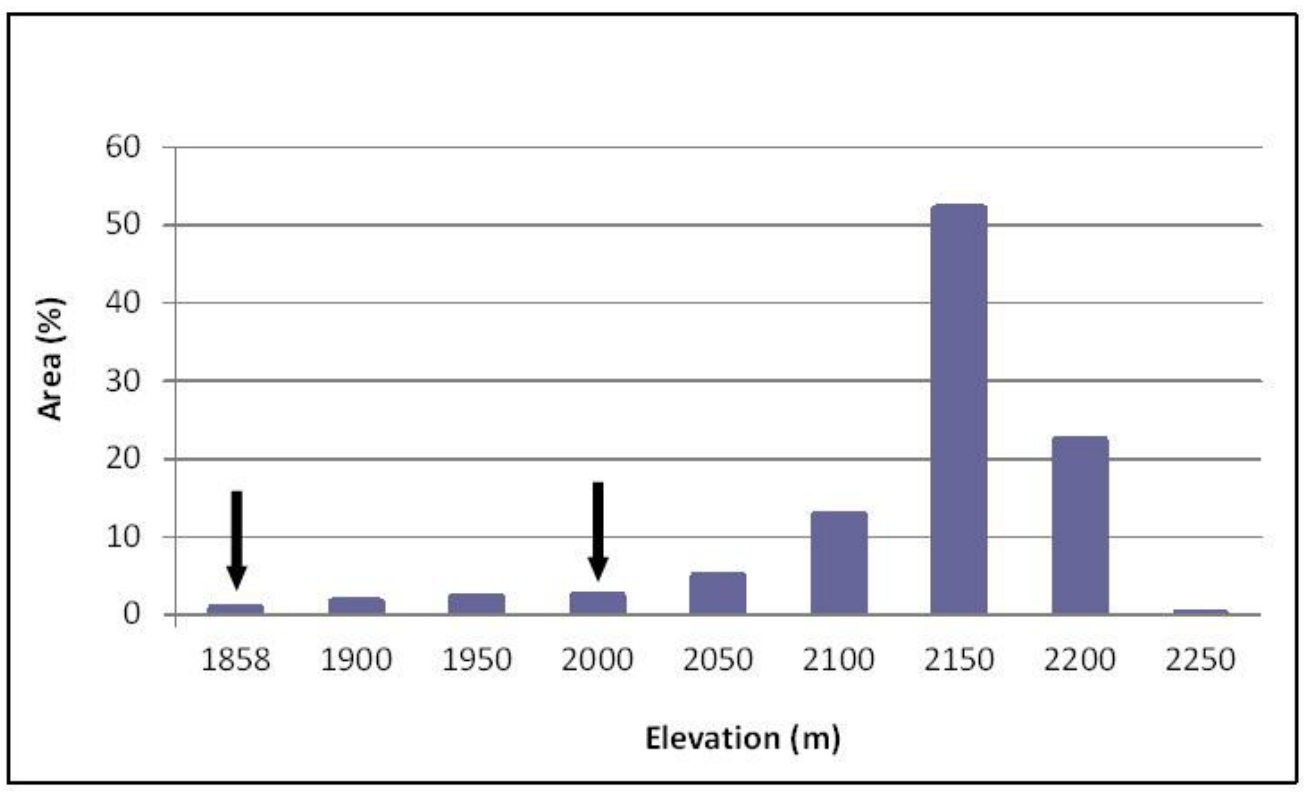

Figure 11: Histogram of Devils Den, Guadalupe Mountains. Arrows represent locations of knickpoints identified from profile analysis. 


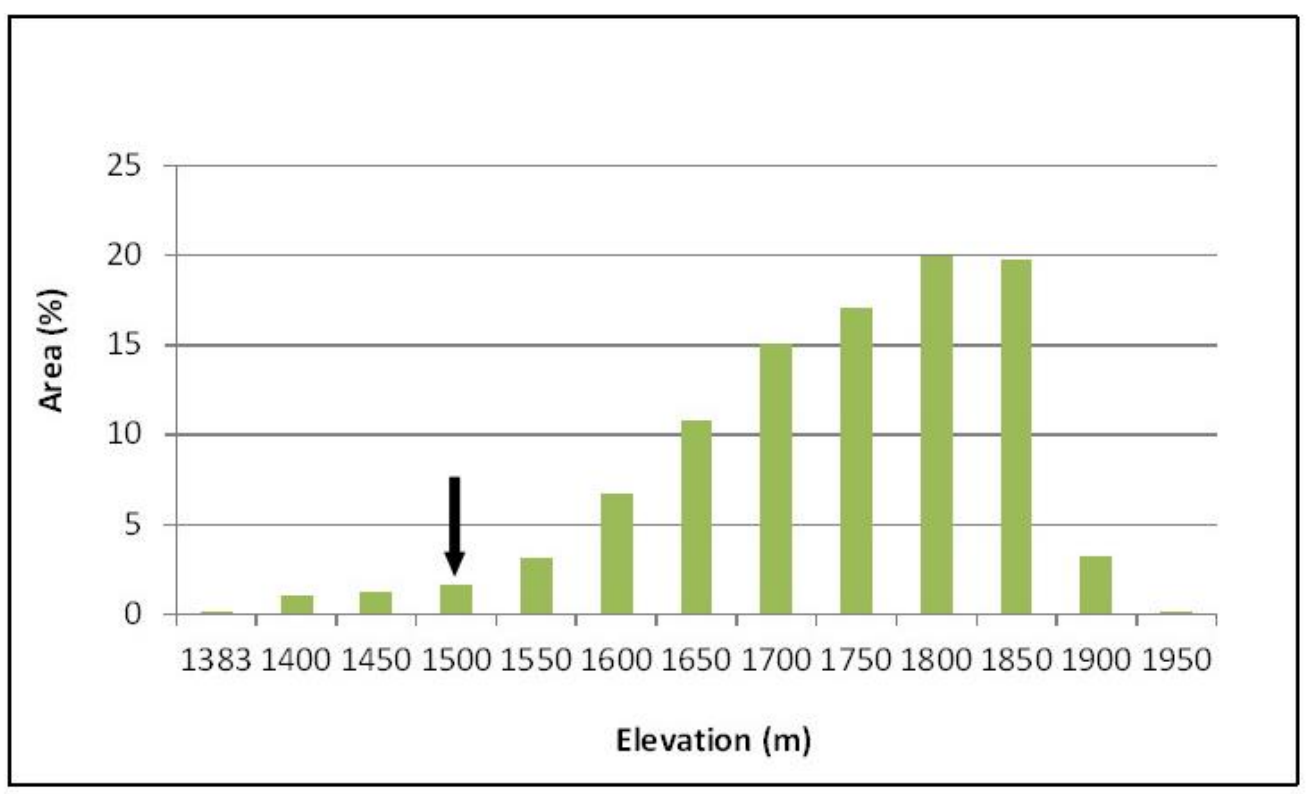

Figure 12: Histogram of Last Chance Canyon, Guadalupe Mountains. Arrows represent locations of knickpoints identified from profile analysis.

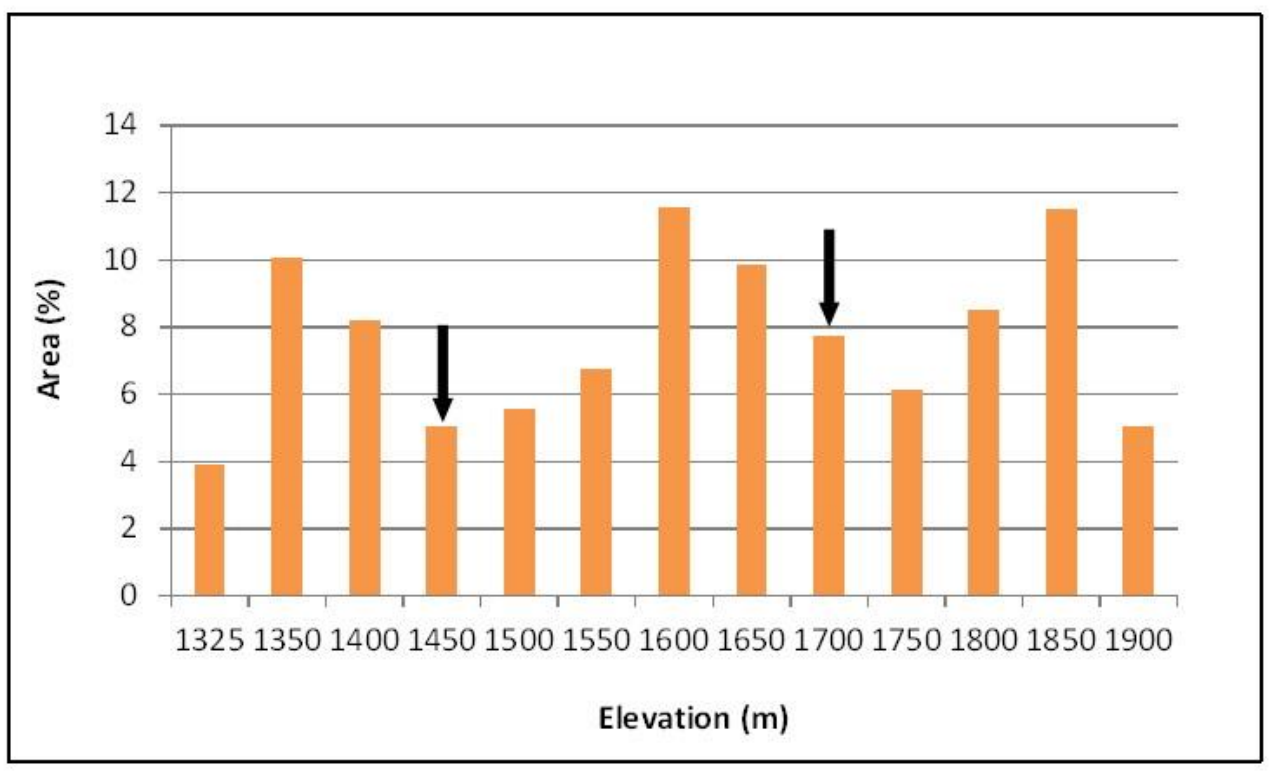

Figure 13: Histogram of Woods Canyon, Guadalupe Mountains. Arrows represent locations of knickpoints identified from profile analysis. 


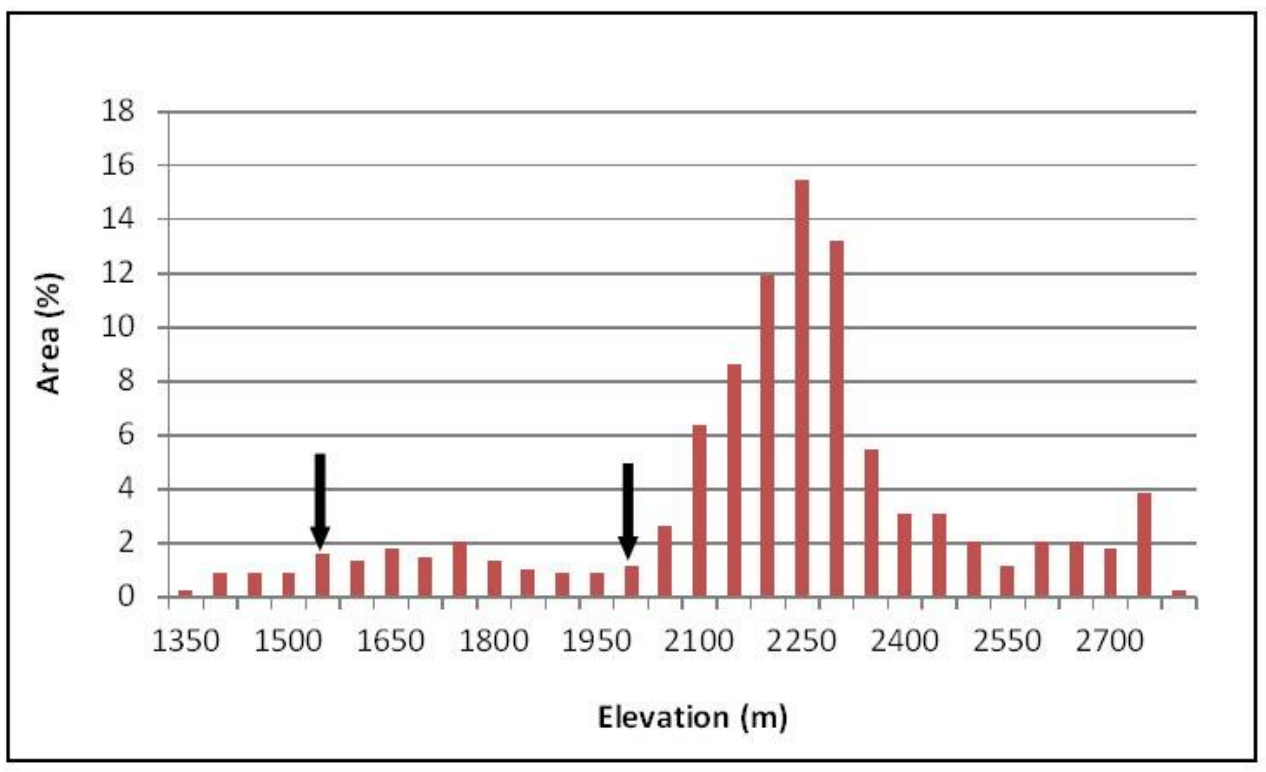

Figure 14: Histogram of Dog Canyon, Sacramento Mountains. Arrows represent locations of knickpoints identified from profile analysis. 


\section{Geologic Distribution}

One final way to predict areas of focused erosion is by analyzing the geology of a catchment and knickpoint locations (figures 15-19). For the Guadalupe Mountains, the upper (1770 m) knickpoint along the North Rim is located in the San Andres formation which consists of dolomite and limestone. The lower (1550 m) knickpoint is located within the Yeso formation which consists of sandstone, siltstone, and interbedded dolomite (figure 15). Devils Den upper (2000 m) and lower (1860 m) knickpoints are located in the Cherry Canyon Sandstone within the Goat Seep Limestone (figure 16). The singular knickpoint along Last Chance Canyon is located in the San Andres formation (figure 17). The upper (1700 m) and lower (1450 m) knickpoints along Wood's Canyon are also located in the San Andres formation (figure 18). In the Sacramento Mountains, the lower (1550 m) knickpoint along Dog Canyon (figure 19) is located in the Percha Shale formation while the upper (2000 m) knickpoint is located in the Gobbler formation which is composed of limestone with traces of sandstone and shale. It was noted during field sampling that sandstone was the slope former and limestone was the cliff former. 

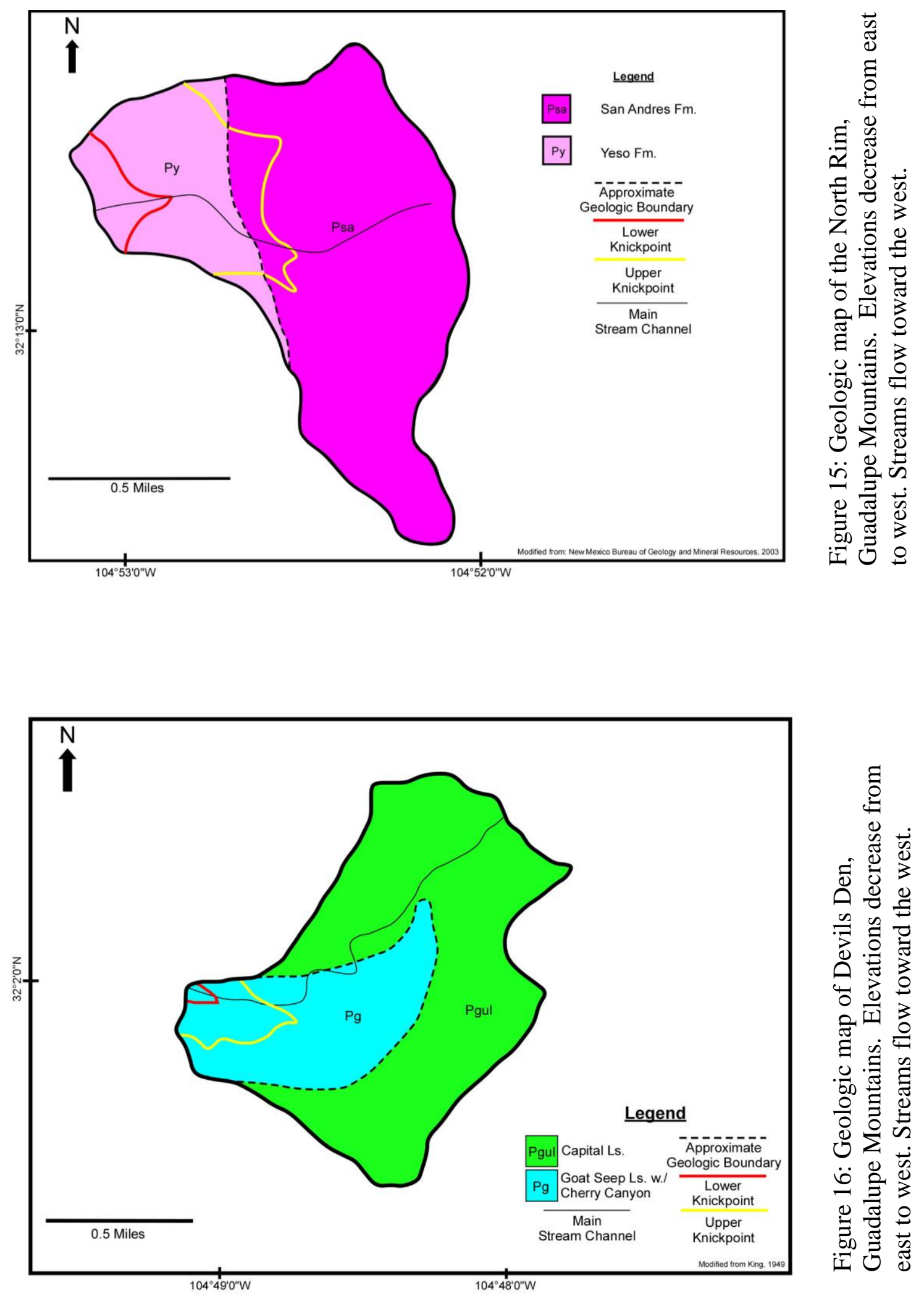

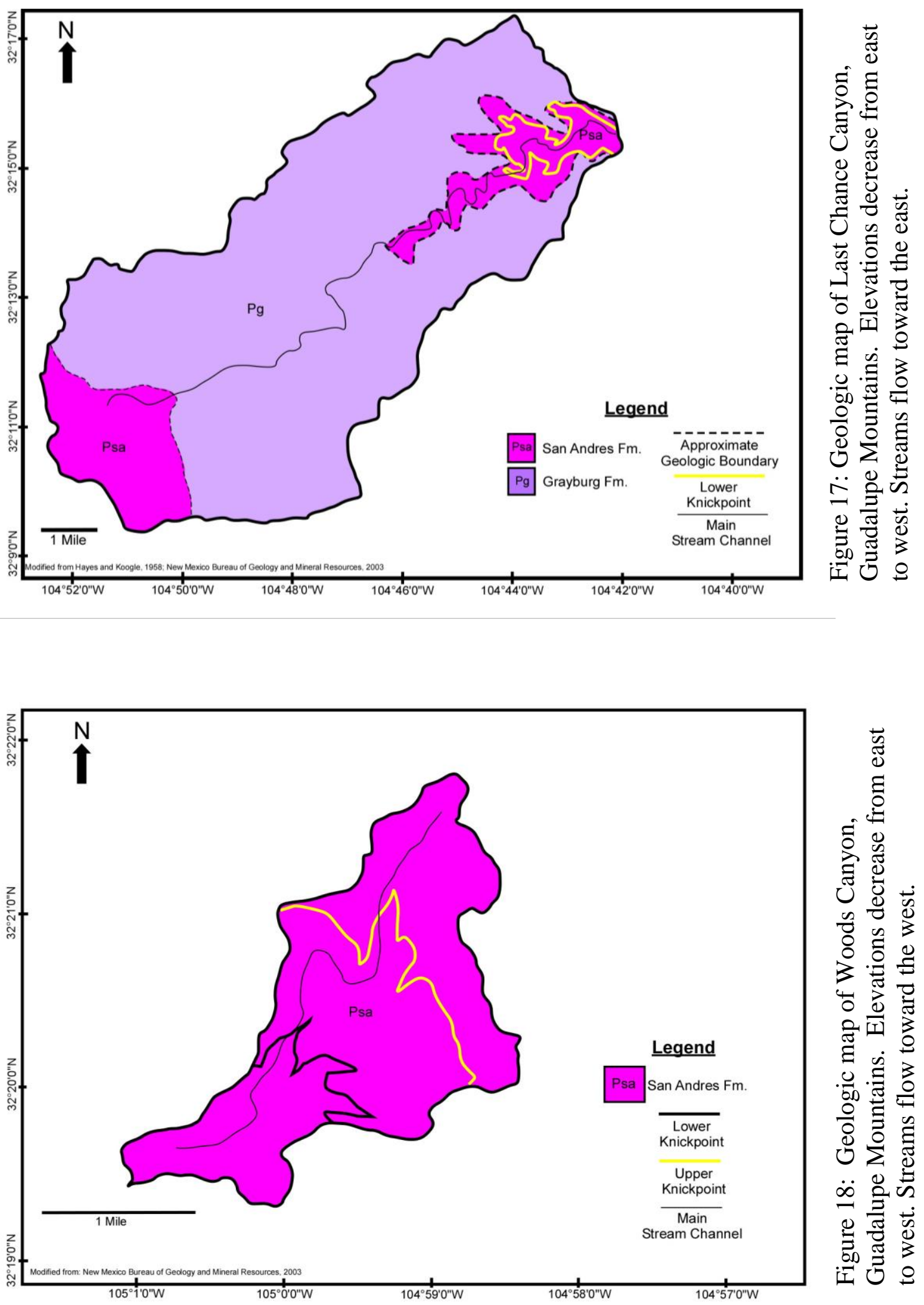


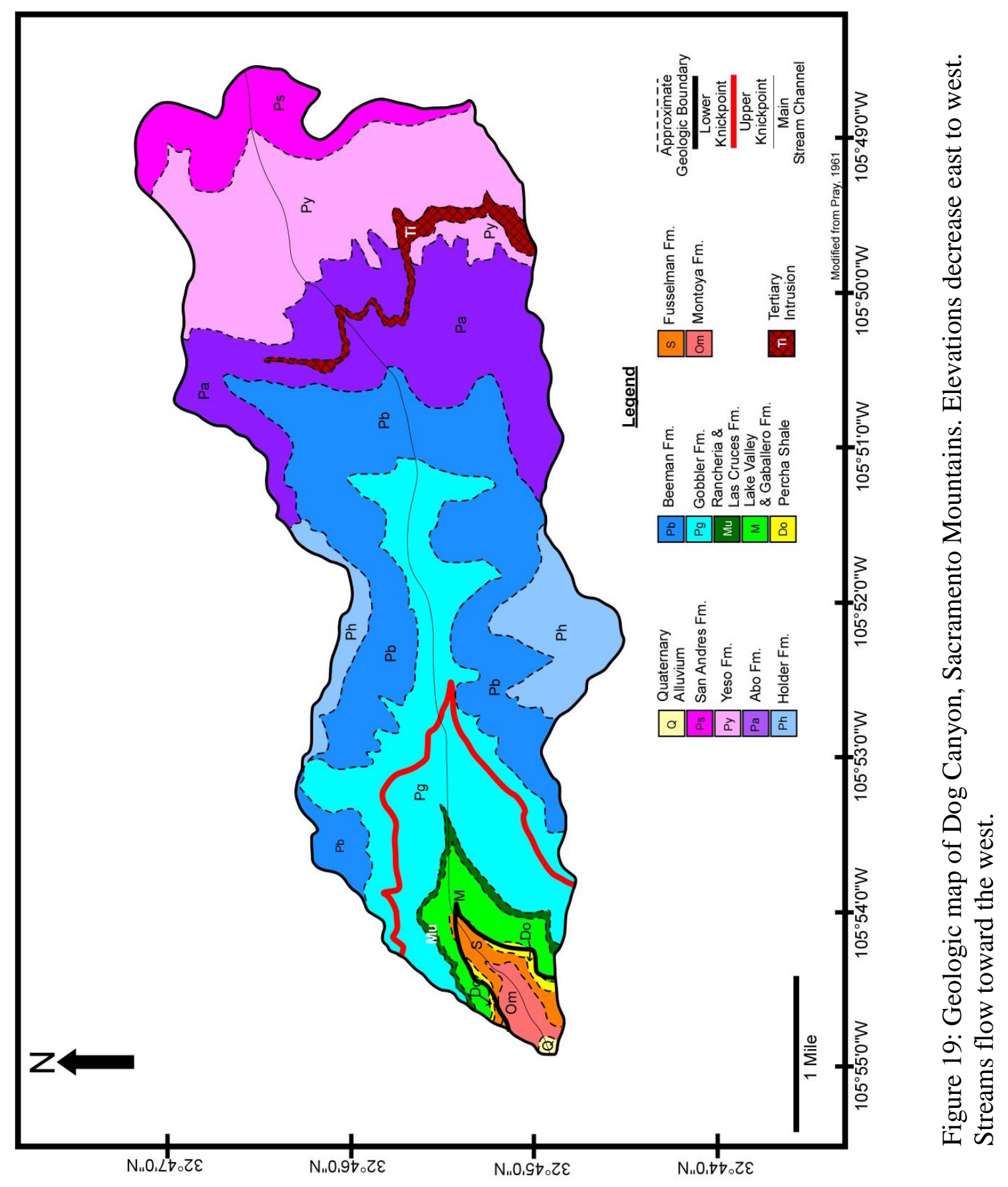




\section{Apatite Cooling Ages}

The bedrock cooling history can help constrain the timing of rift initiation.

Apatite minerals begin trapping helium at $50{ }^{\circ} \mathrm{C}$. The amount of helium trapped can be analyzed and used to produce an age which documents the cooling history of the mineral. Results from bedrock analyses showed that cooling ages were younger than the Permian bedrock ages. Young ages revealed that ages were reset. Ages would have been older than Permian formation ages if they were not reset because it takes millions of years to for a sedimentary rock form from the initial rock the grain originated from. The average age for Guadalupe samples was 26.65 Ma with GMLH1305 ranging in age from 17 38.5 Ma $\pm 10.80 \mathrm{Ma}$ and GU11 ranging in age from 23.6 - 26.7 Ma $\pm 1.56 \mathrm{Ma}$.

Sacramento samples average age (only SM2) was 24.9 Ma with SM2 ranging from 20.7 $29 \mathrm{Ma} \pm 5.87 \mathrm{Ma}$, and GMLH1318 ranging from 4.85 - 6.75 Ma $\pm 1.34 \mathrm{Ma}$.

GMLH1318 was not used in this study because an error occurred with the sample. See table 1 for complete sample details.

Table 1: Sample Information

\begin{tabular}{|c|c|c|c|c|c|c|c|c|c|c|}
\hline $\begin{array}{c}\text { Sample } \\
\text { Name }\end{array}$ & Range & Canyon & $\begin{array}{c}\text { Sample } \\
\text { Type }\end{array}$ & Rock Type & Latitude & Longitude & $\begin{array}{c}\text { Eevation } \\
(\mathrm{m})\end{array}$ & Age (Ma) & SD & $\begin{array}{l}\text { Average } \\
\text { Age (Ma) }\end{array}$ \\
\hline GMLH1302 & Guadalupe & The North Rim & Bedrock & Fine Sandstone & $32.2268 \mathrm{~N}$ & $104.8786 \mathrm{~W}$ & 1835 & - & & - \\
\hline GMLH1303 & Guadalupe & The North Rim & Stream & Sediment & $32.2232 \mathrm{~N}$ & $104.8841 \mathrm{~W}$ & 1564 & - & & - \\
\hline GMLH1305 & Guadalupe & The North Rim & Bedrock & Very Fine Sandstone & $32.2195 \mathrm{~N}$ & $104.8838 \mathrm{~W}$ & 1607 & $17-38.5$ & \pm 10.80 & 28.3 \\
\hline GMLH1317 & Sacramento & Dog Canyon & Stream & Sediment & $32.7489 \mathrm{~N}$ & $105.9198 W$ & 1313 & - & & - \\
\hline GMLH1318 & Sacramento & Dog Canyon & Bedrock & Red Sandy Siltstone & $32.7827 \mathrm{~N}$ & $105.8376 \mathrm{~W}$ & 2401 & $4.85-6.75$ & \pm 1.34 & 5.8 \\
\hline GU11 & Guadalupe & Last Chance Canyon & Bedrock & Sandstone & $32.2329 \mathrm{~N}$ & $104.6284 \mathrm{~W}$ & 1406 & $23.6-26.7$ & \pm 1.56 & 25 \\
\hline SM1 & Sacramento & Dog Canyon & Bedrock & Siltstone & $32.7476 \mathrm{~N}$ & $105.9109 W$ & 1475 & - & & - \\
\hline SM2 & Sacramento & Dog Canyon & Bedrock & Red Sandstone & $32.7491 \mathrm{~N}$ & $105.9069 \mathrm{~W}$ & 1548 & $20.7-29$ & \pm 5.87 & 24.9 \\
\hline SM3 & Sacramento & Dog Canyon & Bedrock & Red Sandstone & $32.7491 \mathrm{~N}$ & $105.9069 \mathrm{~W}$ & 1545 & - & & - \\
\hline SM4 & Sacramento & Dog Canyon & Bedrock & Quart Sandstone & $32.7493 \mathrm{~N}$ & $105.9152 W$ & 1363 & - & & - \\
\hline
\end{tabular}


Bedrock ages from this study were plotted next to bedrock ages calculated from previous studies (Armstrong et al, 2013; Bryant and Naeser, 1980; Kelley and Chapin, 1995 \& 1997; Landman and Flowers, 2013; Maldonado et al, 2013; WoldeGabriel et al, 2013) in order to create minimum, average, and maximum age maps (figures 20-22). Reviewing ages along the eastern margin of the rift the minimum age (figure 20) and average age (figure 21) maps showed that ages from this study, except GMLH1305, were within the same magnitude ( 22-26 Ma) as others. The maximum age (figure 22) map showed ages from this study to be slightly younger ( 4-10 Ma younger) than what others previously found. However, if uncertainty is taken into account, ages from this study all fall into the same magnitude as what others calculated, except for GMLH1305 with its large degree of uncertainty $( \pm 10.80 \mathrm{Ma})$. Upon map comparison, trends were found between all three maps. Ages located in southern New Mexico revealed ages get older as you move from the central rift toward the eastern margin. A north-south trend was also found between the average and minimum age maps showing as you go from north to south ages get younger. This trend was not found on the maximum Age map. 


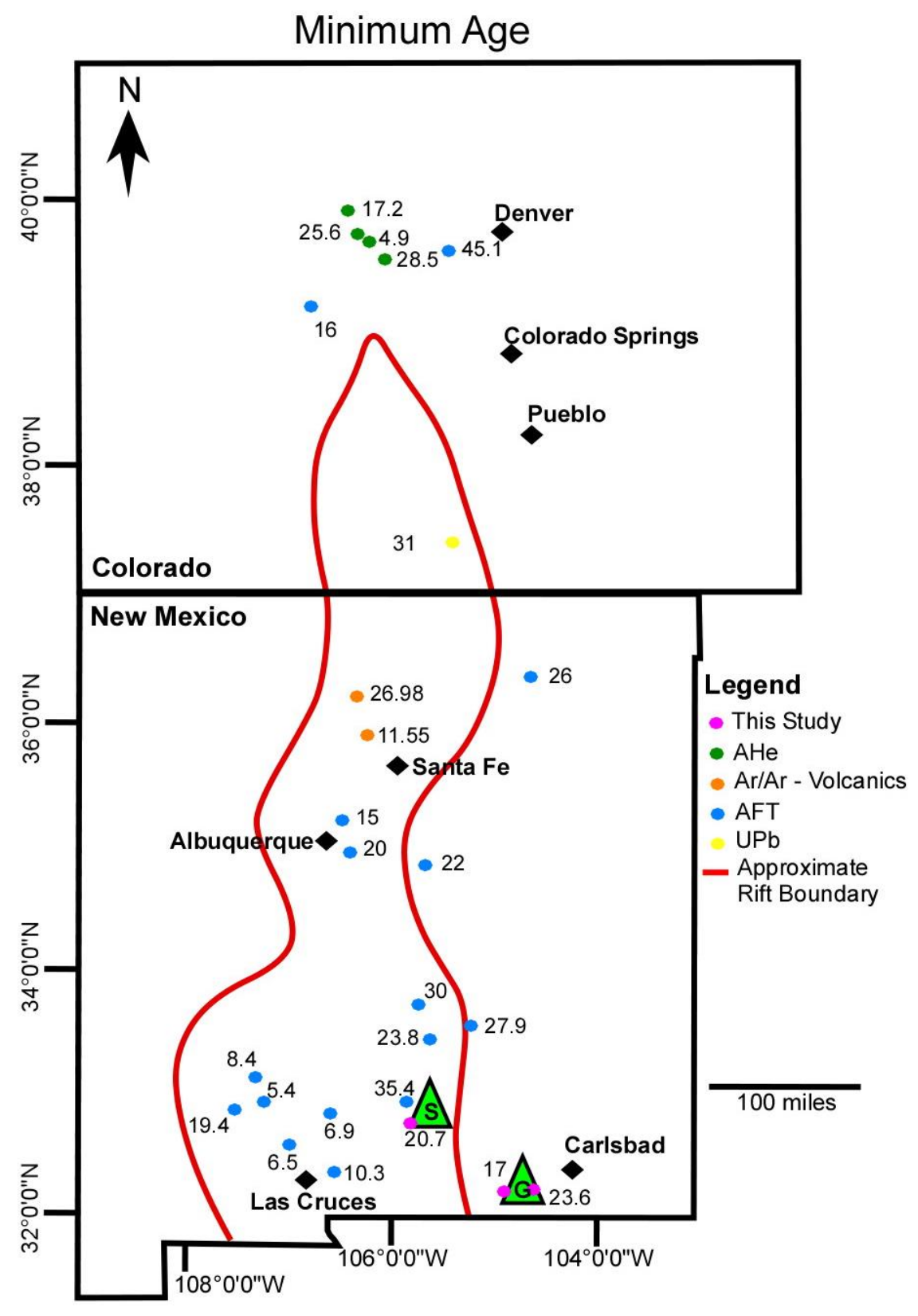

Figure 20: Minimum age map. Triangle S represents the Sacramento Mountains and triangle $\mathrm{G}$ represents the Guadalupe Mountains. Dots represent the different age dating techniques. All ages are reported in Ma. (Additional ages from: Armstrong et al, 2013; Bryant and Naeser, 1980; Kelley and Chapin, 1995 \& 1997; Landman and Flowers, 2013; Maldonado et al, 2013; WoldeGabriel et al, 2013) 


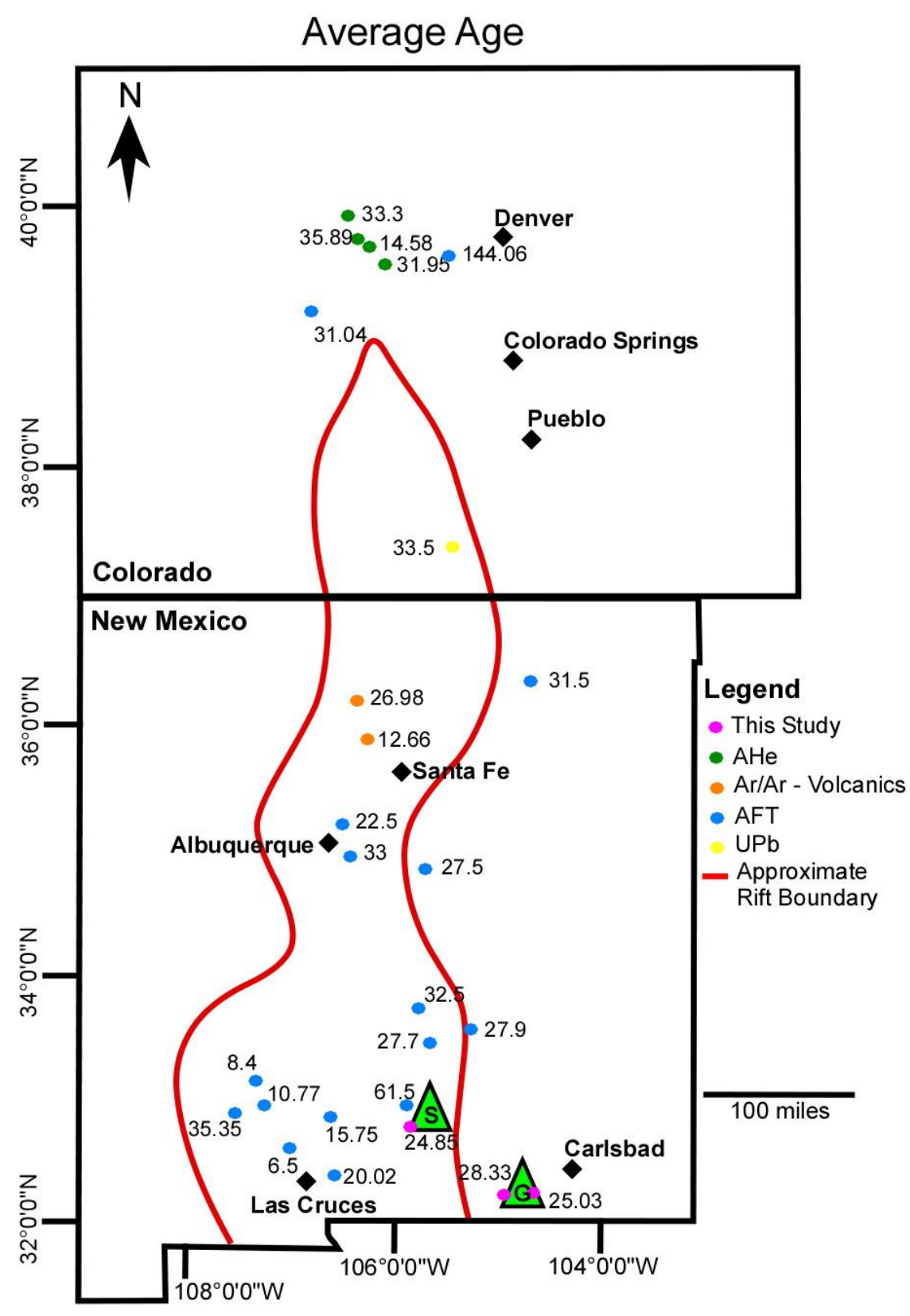

Figure 21: Average age map. Triangle S represents the Sacramento Mountains and triangle $\mathrm{G}$ represents the Guadalupe Mountains. Dots represent the different age dating techniques. All ages are reported in Ma. (Additional ages from: Armstrong et al, 2013; Bryant and Naeser, 1980; Kelley and Chapin, 1995 \& 1997; Landman and Flowers, 2013; Maldonado et al, 2013; WoldeGabriel et al, 2013) 


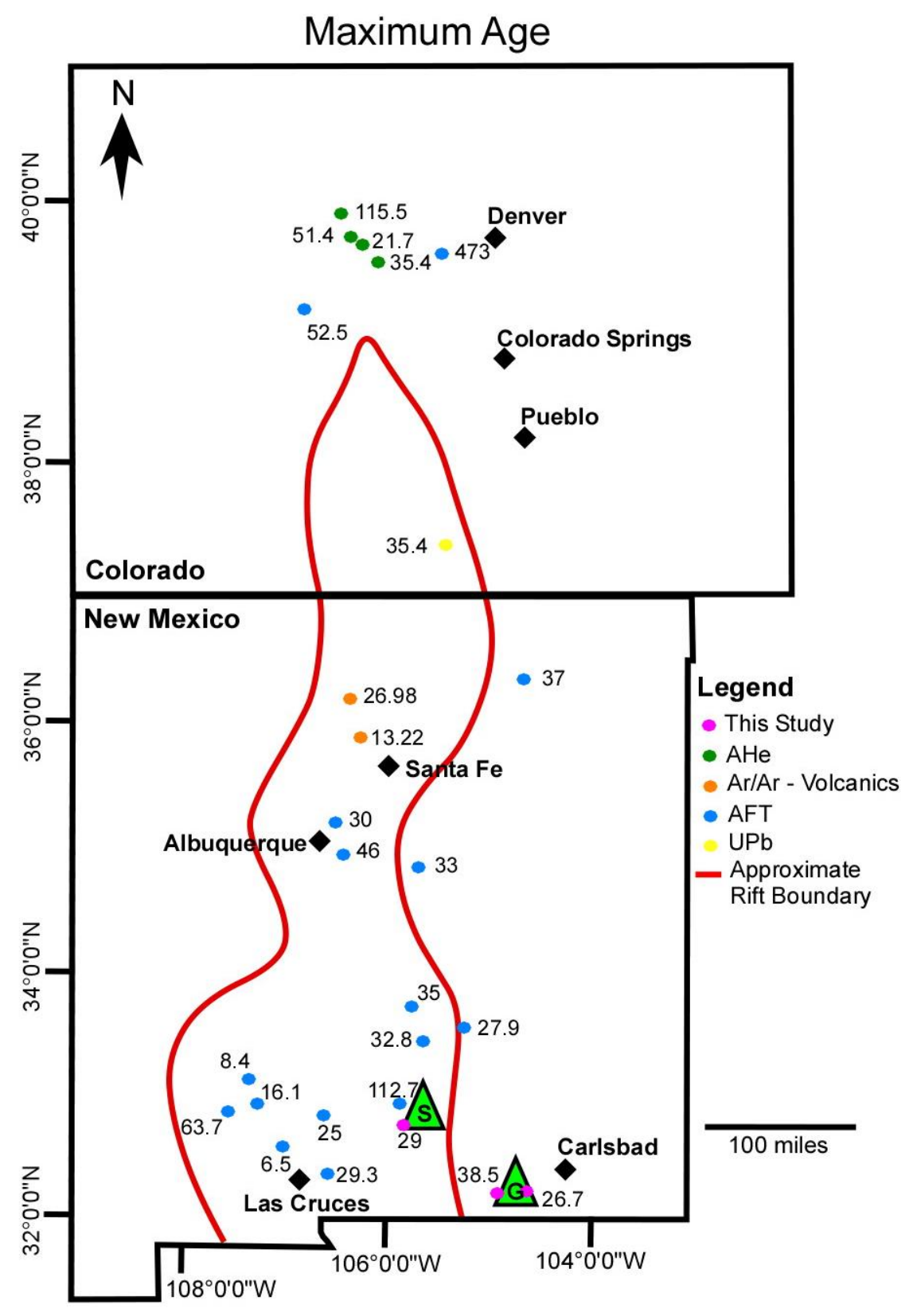

Figure 22: Maximum age map. Triangle S represents the Sacramento Mountains and triangle $\mathrm{G}$ represents the Guadalupe Mountains. Dots represent the different age dating techniques. All ages are reported in Ma. (Additional ages from: Armstrong et al, 2013; Bryant and Naeser, 1980; Kelley and Chapin, 1995 \& 1997; Landman and Flowers, 2013; Maldonado et al, 2013; WoldeGabriel et al, 2013) 


\section{Age - Elevation Gradient and Bedrock Age Distribution}

The distribution of bedrock cooling ages within a canyon defines the tracer for sediment sources. Bedrock ages for the North Rim were plotted against elevations (figure 23) to calculate the equation of a line (equation 2). A bedrock age distribution map for the Guadalupe Mountain's North Rim was then created and is shown in figure

24. Ages for each knickpoint were identified from the map. The age of the upper North Rim knickpoint (grey) was determined to be 30-31 Ma and the lower knickpoint (black) 26-27 Ma. The age associated with the upper knickpoint is the same as when rifting first began $30 \mathrm{Ma}$. Due to sample problems, an age map was not generated for Dog Canyon in the Sacramento Mountains.

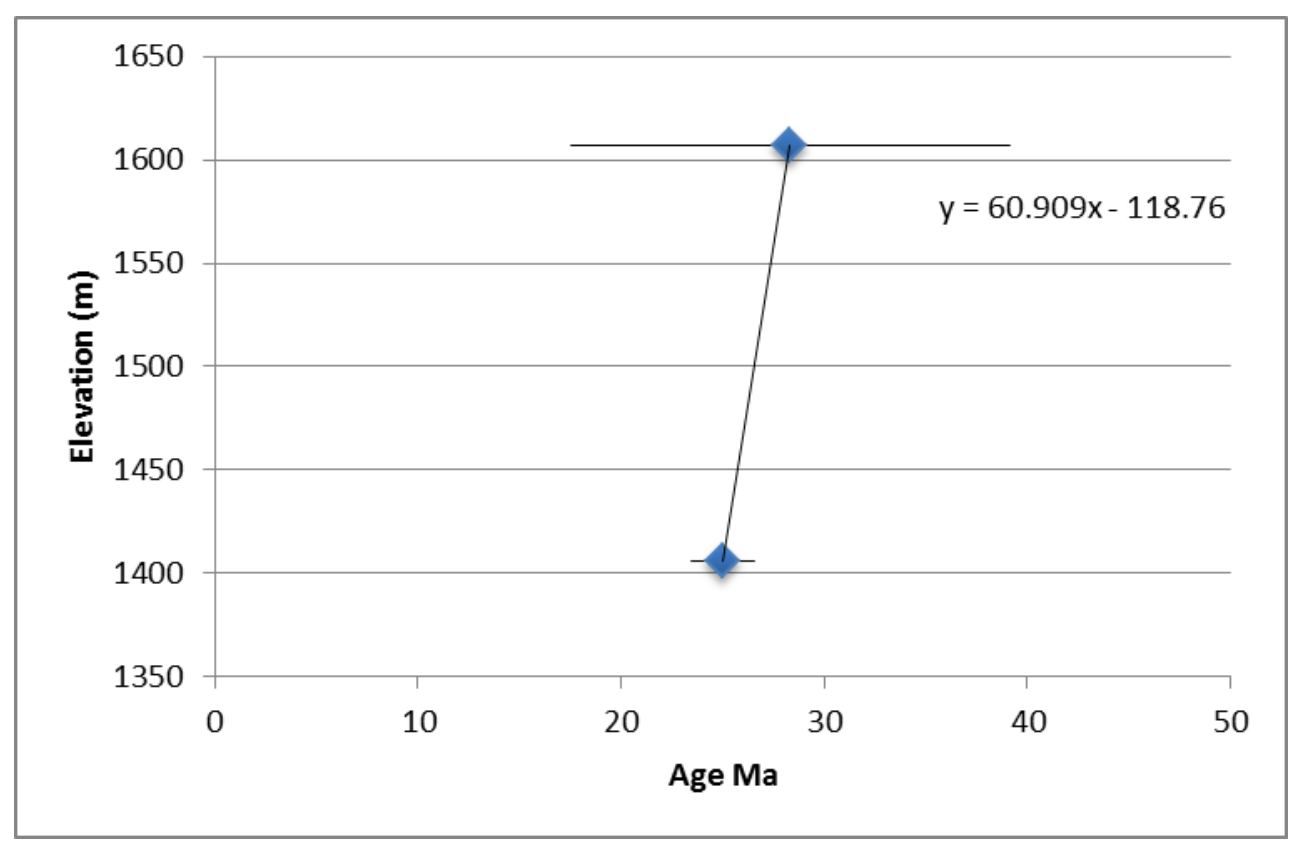

Figure 23: Age - elevation graph for the North Rim, Guadalupe Mountains 


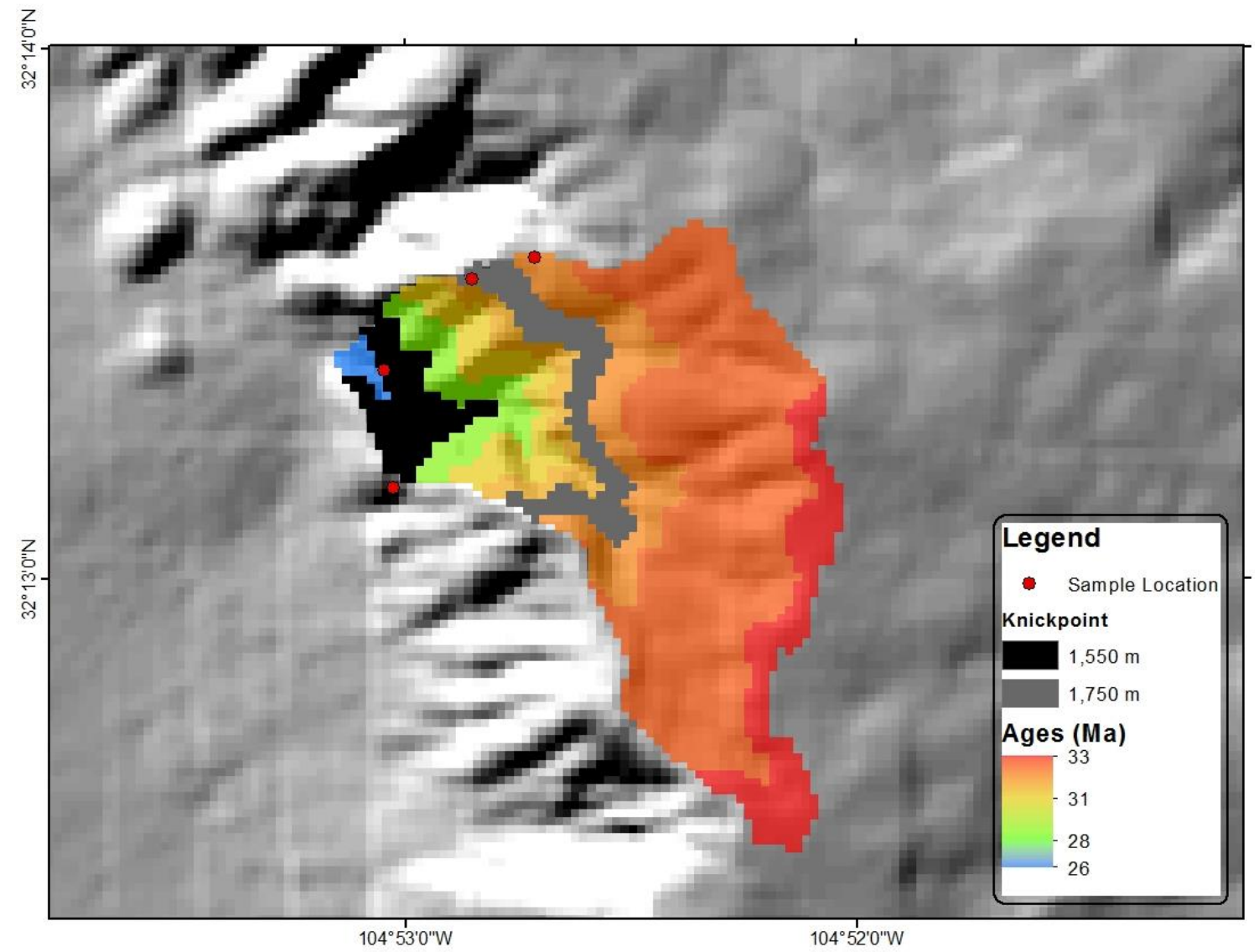

Figure 24: Bedrock age distribution map of the North Rim, Guadalupe Mountains. 


\section{Predicted Sediment Age Distribution}

Sediment collected from the mouth of a canyon provides a distribution of ages that can be traced back to their source bedrock in the canyon. Sediment age distributions tell whether a canyon is at steady state (equal amounts of erosion) or is actively eroding due to regional tectonics (focused erosion) (Rhul and Hodges, 2005). Bedrock grain ages from the Guadalupe Mountains were used to generate random sample points that represent the predicted distribution of erosion if all surfaces are eroding equally. These points were used to generate the probability density function for the North Rim (figure 25). Results from the probability density function revealed a high probability for grain ages to be between 28 - $35 \mathrm{Ma}$ with the most likely age being $31 \mathrm{Ma}$. This age corresponds to the upper knickpoint age from the North Rim and is also very similar to maximum bedrock ages for the Guadalupe Mountains as well as maximum ages from other studies. The original plan was to compare a pdf of actual sediment ages to the pdf from the randomly sampled points, however poor quality of apatite grains in the sediment samples resulted in unusable sediment cooling ages.

I also assessed the change in PDF if uncertainty values changed. Values were determined from the age uncertainty and average age of each sample. Figure 26 shows the results as you increase the uncertainty from $10 \%$ to $40 \%$. Changing the uncertainty associated with calculated ages revealed that the age range significantly increased and the probability decreased as uncertainty increased. 


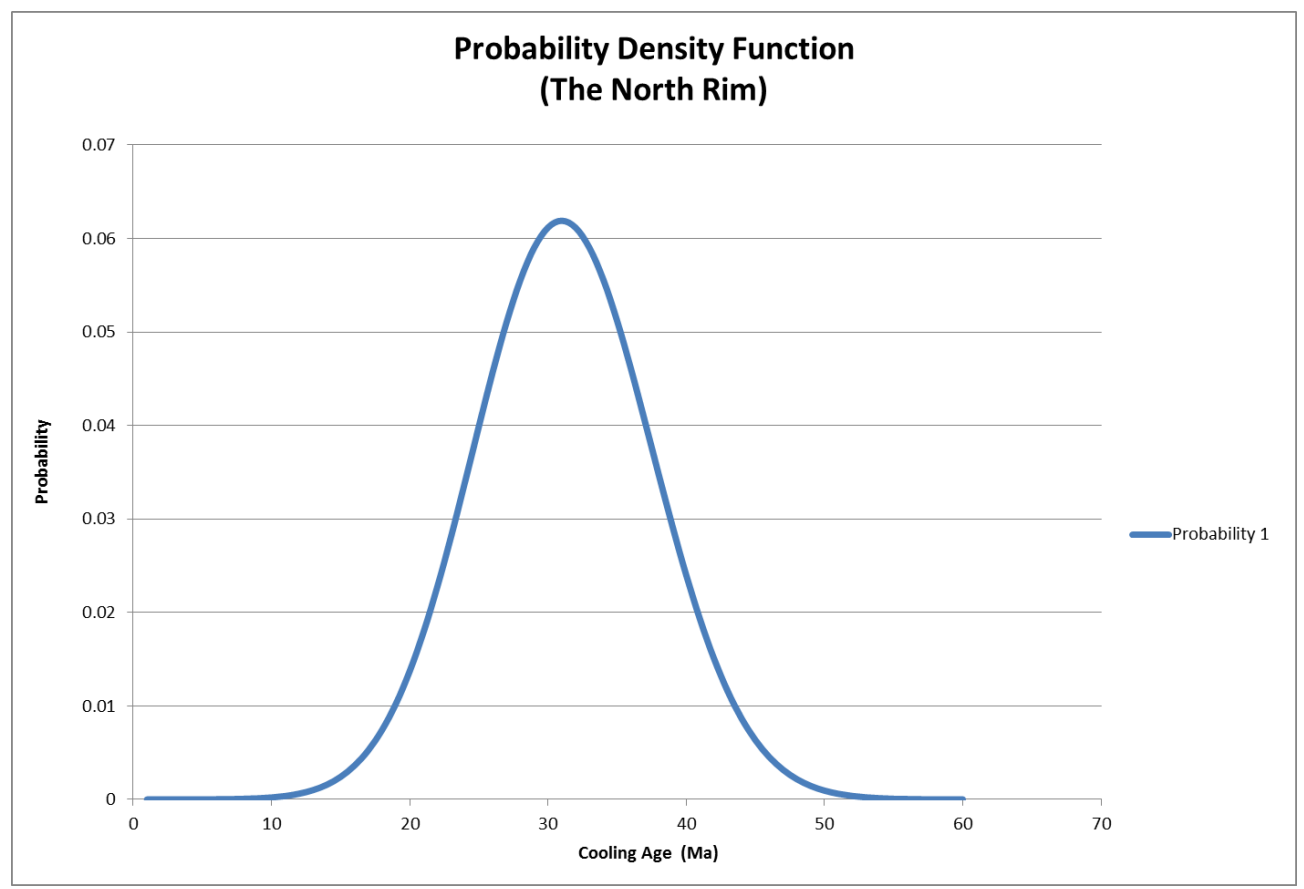

Figure 25: Graph of the probability density function for the North Rim, Guadalupe Mountains

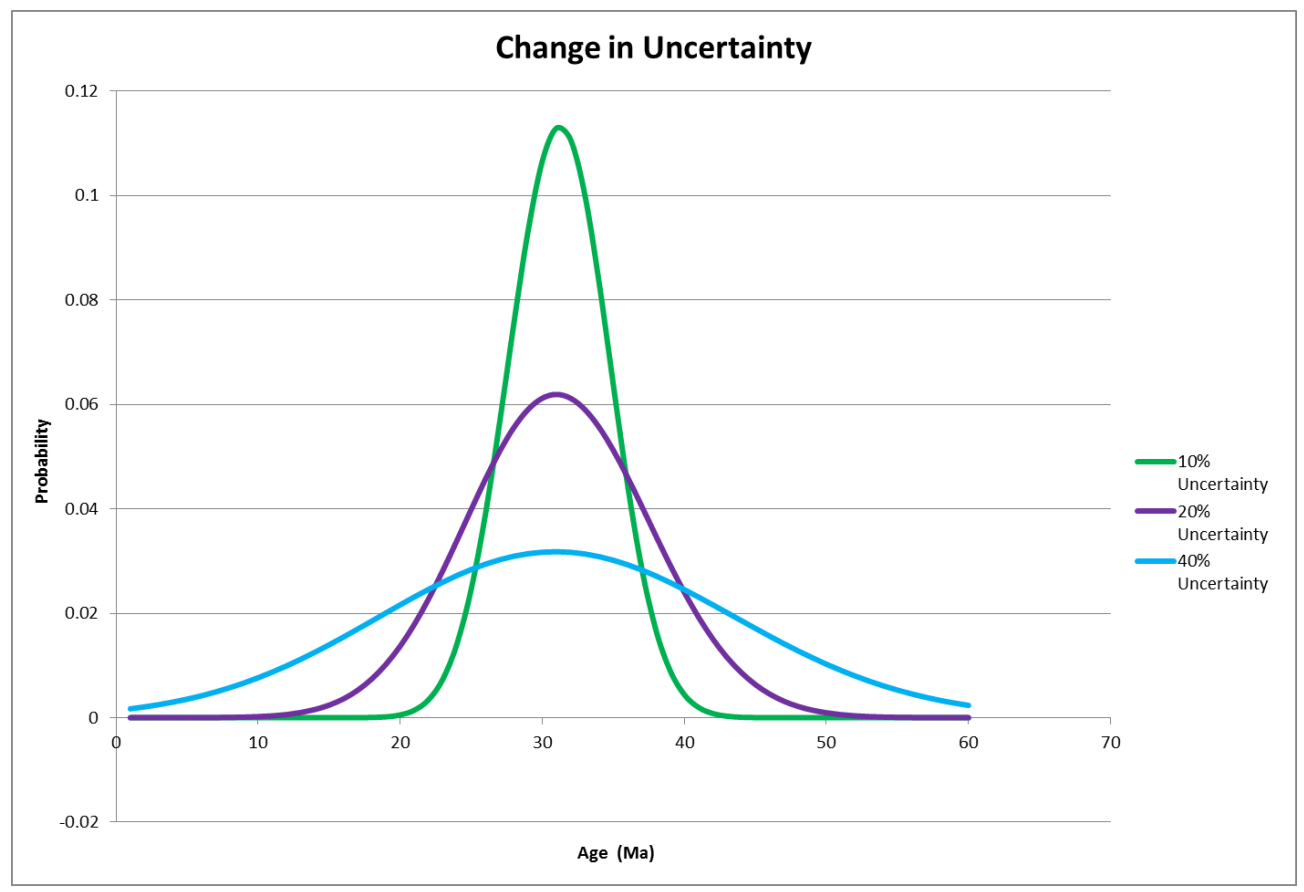

Figure 26: Graph of the change in uncertainty for the North Rim, Guadalupe Mountains 


\section{Apatite Size and Quality}

The quality of grains was also assessed due problems encountered with samples. AHe sediment analysis results indicate that some grains may not have been apatite, due to low helium concentrations. Sediment grain photos were re-examined to determine if grains were rectangular prisms or circular shaped. Grains that displayed a rectangular shape were considered to be apatite (due to apatite's hexagonal crystal system) and circular shaped grains were considered to be potentially another mineral (e.g. fluorite, due to its cubic crystal system). Table 2 shows the percent of grains analyzed that had a "good" shape. "Good” referring to rectangular prisms. Sediment samples GMLH1317 and GMLH1303 had the best shaped grains. Many of the bedrock grains picked were rounded and circular in shape, except for GMLH1318 with $71 \%$ of the grains displaying a good crystal shape. For individual grain details see Appendix A.

Table 2: Grain Data

\begin{tabular}{l|l|c|c|c}
$\begin{array}{l}\text { Sample } \\
\text { Name }\end{array}$ & \multicolumn{1}{c}{$\begin{array}{c}\text { Sample } \\
\text { Type }\end{array}$} & \multicolumn{1}{c}{$\begin{array}{c}\text { Width } \\
\text { (um) }\end{array}$} & $\begin{array}{c}\text { \% } \\
\text { um } 70\end{array}$ & $\begin{array}{c}\text { \% Good } \\
\text { Shape }\end{array}$ \\
\hline GMLH1302 & Bedrock & $40-80$ & 33 & 40 \\
GMLH1303 & Stream & $20-80$ & 35 & 85 \\
GMLH1305 & Bedrock & $40-70$ & 43 & 47 \\
GMLH1317 & Stream & $40-90$ & 35 & 100 \\
GMLH1318 & Bedrock & $20-50$ & 0 & 71 \\
GU11 & Bedrock & $40-80$ & 74 & 25 \\
SM1 & Bedrock & - & - & - \\
SM2 & Bedrock & $20-50$ & 7 & 42 \\
SM3 & Bedrock & - & - & - \\
SM4 & Bedrock & - & - & -
\end{tabular}

The size of the grain width also influenced age calculations. Grains with a diameter $<70$ um did not contain enough uranium to allow accurate age calculations. 
Table 2 displays the percent of grains picked that had widths of greater than $70 \mathrm{um}$. Sediment grain widths ranged from 20 - 90 um and bedrock grain widths ranged from 20 - 80 um. Results showed that only GU11 had a high amount of grains (74\%) that had widths greater than $70 \mathrm{um}$. The rest of the samples had a much lower percent ranging from $0 \%$ to $43 \%$. 


\section{CHAPTER IV \\ DISCUSSION}

\section{Spatial Patterns of Erosion}

Identifying spatial patterns of erosion proves to be a useful way of understanding how tectonics influence the landscape without having to visit each location. Identifying convexities, knickpoints, along longitudinal profiles proves to be a useful way to identify areas of erosion. I hypothesized that erosion will be prominent at knickpoint locations and also at higher elevations. The analysis showed that the most area existed at higher elevations however; knickpoints did not exist within those areas. Upper knickpoints associated with figures $10,11,12$, and 14 are located just below high percent areas. I interpreted upper knickpoints to be associated with resistant rock units causing erosion to occur very slowly. This is because the slower the erosion, the larger the percent area. Lower knickpoints from all five catchments did not exist near large percent areas. The distribution of lower knickpoints also led me to believe that they are fault related. The North Rim (1550 m) and Woods Canyon (1450 m) knickpoints are so close in elevation that I interpreted them to be caused by the same fault. Other faults probably exist through the area and are the source for the other knickpoints. This would reveal that faults are not continuous and are not perfectly straight lined features.

Comparison of knickpoint locations to randomly sampled predicted sediment ages also did not show any correlation. One reason is because if upper knickpoints are located 
in more resistant material very little erosion will occur and ages will not be associated to that knickpoint. If there is very little erosion then the age distribution will not be focused at the knickpoint, and instead the age distribution will be equal for the canyon. Lower knickpoints also have the potential of being associated with more resistant rock units which could be the reason for not seeing related ages associated with knickpoint ages. However, I interpreted the lower knickpoints to be associated with faulting. My reason behind faulting is because of lower knickpoint elevations and because of the semiarid nature of the region. The lower knickpoints, especially the North Rim and Woods Canyon have knickpoints at relatively the same elevations. I interpreted the knickpoints to be the product of faulting and associated to one another because of their elevations (figures 10 and 13). On the other hand, because of the close proximity of some of the lower knickpoints (e.g. Woods Canyon and the North Rim) they could be associated with the same continuous rock unit. This would mean that those lower knickpoints are probably part of a more resistant rock unit. The other knickpoint elevations are not similar to one another. I determined them to be affiliated with other faults that are not connected to one another. The current erosional mechanism is water. Rapid precipitation occurs about once a year causing flash flooding along both mountain ranges. Because of the arid climate, flash floods carry much sediment that scours and transports material during high energy events. However, because of resistant rock units, water will erode material very slowly causing predicted sediment grain ages to not be related to knickpoint ages. Note that this can only be assumed for the Guadalupe Mountain's North Rim. Predicated sediment ages were only calculated for the North Rim because of poor 
sediment apatite grain quality. These findings do not support my hypothesis, but they do reveal that there is erosional resistance between both ranges.

The majority of the knickpoints identified are located in resistant rock units that are composed of limestone and dolomite. Limestone and dolomite are the dominant geology throughout each canyon with smaller traces of sandstone as interbedded units. I interpreted that the carbonates were the resistant units, which was verified during sample collection. This confirms my hypothesis that resistant units make up a greater portion of the elevation area. Geologic maps (figures 15-19) confirm that resistant rock units (e.g. limestone and dolomite) make up the higher elevation areas. Carbonates dominate the higher areas, and lower areas have carbonates with interbedded sandstone units.

\section{Timing of Exhumation}

The occurrence of late Tertiary AHe cooling ages in the Guadalupe and Sacramento Mountains indicates exhumation during that time. This result is compliant to previously published AFT data by Kelley and Chapin (1997) conducted in southern New Mexico. AHe thermochronology data in my study recorded an average Guadalupe Mountain age of $26.65 \pm 6.18 \mathrm{Ma}$ and an average Sacramento Mountain age of $24.9 \pm$

5.87 Ma. These cooling ages verify my hypothesis that ages were reset and are consistent with the Rio Grande Rift evolution. Reset ages indicate that prior to rifting, grains were buried deep enough $(\sim 3 \mathrm{~km})$ to become reset and record an initial age of 0 Ma. Tertiary rifting initiated normal faulting causing the footwall to become uplifted and the hanging wall to drop. Grains in the footwall cooled and began recording fault initiation. 
Exhumation of the footwall then led to grains becoming exposed at the surface where samples were collected and analyzed.

Extension along the rift and subsequent faulting led to $\sim 1.6 \mathrm{~km}$ of exhumation along the footwall. Applying an initial average geothermal gradient from the Rio Grande rift of $\sim 30{ }^{\circ} \mathrm{C} / \mathrm{km}$ (Reiter et al., 1978) to a $50{ }^{\circ} \mathrm{C}$ closure temperature (Landman and Flowers, 2013) for He in apatite implies $~ 1.6 \mathrm{~km}$ of exhumation/uplift occurred along the eastern margin of the rift. This result is $0.2 \mathrm{~km}$ different than what Landman and Flowers (2013) saw for the eastern margin of the Gore Range in central Colorado. Using a geothermal gradient for the Gore Range of $\sim 35^{\circ} \mathrm{C} / \mathrm{km}$ and a closure for He in apatite of $50{ }^{\circ} \mathrm{C}$, Landman and Flowers determined $\sim 1.4 \mathrm{~km}$ of sediment was unroofed from the eastern margin of the southern Gore Range since 10 Ma. Changing the geothermal gradient also affects the amount of sediment exhumed. If a lower geothermal gradient is used, e.g. $25^{\circ} \mathrm{C} / \mathrm{km}$, the amount of exhumed sediment increases to $\sim 2 \mathrm{~km}$. If a higher geothermal gradient is used, e.g. $40{ }^{\circ} \mathrm{C} / \mathrm{km}$, the amount decreases to $\sim 1.25 \mathrm{~km}$. In comparison, if the closure temperature changes the amount of exhumed sediment also changes. Using the $30{ }^{\circ} \mathrm{C} / \mathrm{km}$ geothermal gradient, if the closure temperature increases to $70{ }^{\circ} \mathrm{C}$, the amount of sediment exhumed increases to $\sim 2.33 \mathrm{~km}$ and if the closure temperature decreases to $40{ }^{\circ} \mathrm{C}$, the amount decreases to $\sim 1.33 \mathrm{~km}$. Because the amounts are so similar it is assumed that between $1.4-1.6 \mathrm{~km}$ of sediment have been exhumed and uplifted at a rate of $0.053 \mathrm{~mm} / \mathrm{yr}$ since $30 \mathrm{Ma}$.

My results provide additional evidence supporting hypotheses that rifting occurred from 26-29 Ma throughout New Mexico and southern Colorado. Rift propagation was thought to be northward (Leonard, 2002; Reiter and Chamberlin, 2011) 
with ages younging to the north. This trend was not seen on the age maps compiled in my study. Instead ages decreased slightly to the south indicating that propagation might have been southward; however the distribution of ages in figures 20-22 are very similar and could infer that there is no age trend meaning that rifting was simultaneous throughout New Mexico and southern Colorado. Landman and Flowers (2013) support this interpretation. They concluded that their AHe ages $(6.9 \pm 2.8$ to $41.8 \pm 5.3 \mathrm{Ma})$ were very similar to other rift flank uplifts to the south and suggested that rifting occurred simultaneously during the Tertiary (Landman and Flowers, 2013). In addition, Chapin and Cather (1994) also found that rifting occurred at the same time from 29-26 Ma from central New Mexico through southern Colorado using Ar/Ar data obtained from previous studies.

\section{Apatite Quality}

As with every study challenges arose. The challenges encountered were related to apatite grain analysis and included: the size of grain widths, grain shape, grain roundness, and mineral identification. All of these complications affected the amount of helium each grain retained and ultimately the age. I addressed these challenges by determining grain parameters. Table 2 shows the percentage of good grains. Many of the gains picked for my analysis were too small in diameter. The ideal grain width was determined by Reiners and Farley (2001), who stated that grain widths should be a minimum, if not greater than $70 \mathrm{um}$ to ensure enough helium is retained within the grain to produce high enough helium concentrations for age calculations. I also determined that the shape of grains should resemble their crystal structures, in this case rectangular prisms. This is because many of the grains did not display distinct crystal shape. Meester and Dunai 
(2002) discussed that ideal grain shapes should be cylinders to ensure helium retention. Lastly, I determined that, if possible, grains should not be rounded; however, if they are, should be oval in shape. This is to ensure that grains are being properly identified. Grains that are incorrectly identified have the potential of producing low or overly high helium concentrations and obscure ages.

Time was also a challenge faced with this study. The amount of time involved to process each sample ( 1 week for each sample) and wait for results ( 4-6 months) is lengthy. This affects the quantity of samples able to be processed and puts time constraints on when samples need to be processed by. 


\section{CHAPTER V CONCLUSIONS}

The Rio Grande rift proves to be an interesting North American structure to analyze. The ongoing debate between its extent and influence on surrounding areas has also contributed to it being an ideal location of study. Cooling histories determined from AHe analysis show that in the beginning stages of rifting ( $\sim 30 \mathrm{Ma})$ the Guadalupe and Sacramento Mountains were affected. This is true for the entirety of the eastern margin of the Rio Grande rift as seen from the age maps. Over the course of $30 \mathrm{Ma}$ approximately 1.4-1.6 $\mathrm{km}$ of sediment has been exhumed across the eastern margin at a rate of $0.053 \mathrm{~mm} / \mathrm{yr}$. More rock samples need to be collected to fully understand the amount of sediment exhumed and to better determine the cooling age of rock samples from the Guadalupe and Sacramento Mountains. Spatial distributions of erosion revealed that carbonates dominate both ranges and are the cause of upper knickpoints while the lower knickpoints are a result of faulting. Geology is the primary controlling factor affecting erosion. More resistant material, e.g. limestone, causes rocks to erode and at much slower rate. In addition, the semiarid nature of the region also means that erosion is occurring at a very slow rate because water is only available during large precipitation events. 


\section{REFERENCES}

Adams, D.C. and Keller, G.R., 1994, Crustal structure and basin geometry in southcentral New Mexico, in Keller, G.R., and Cather, S.M., eds., Basins of the Rio Grande Rift: Structure, Stratigraphy, and Tectonic Setting: Boulder, Colorado, Geological Society of America Special Paper 291, p. 241-255.

Armstrong, C., Dutrow, B.L., Henry, D.J., and Thompson, R.A., 2013, Provenance of volcanic clasts from the Santa Fe Group, Culebra graben of the San Luis Basin, Colorado: A guide to tectonic evolution, in Hudson, M.R., and Grauch, V.J.S., eds., New Perspectives on Rio Grande Rift Basins: From Tectonics to Groundwater: Geological Society of America Special Paper 494, p. 21-45.

Barrow, R. and Keller, G.R., 1994, An integrated geophysical study of the Estancia Basin, central New Mexico, in Keller, G.R., and Cather, S.M., eds., Basins of the Rio Grande Rift: Structure, Stratigraphy, and Tectonic Setting: Boulder, Colorado, Geological Society of America Special Paper 291, p. 171-186.

Bryant, B. and Naeser, C.W., 1980, The significance of fission-track ages of apatite in relation to the tectonic history of the Front and Swatch Ranges, Colorado, Geological Society of America Bulletin, Part 1, v. 91, p. 156-164.

Chapin, C.E., and Cather, S.M., 1994, Tectonic setting of the axial basins of the northern and central Rio Grande rift, in Keller, G.R., and Cather, S.M., eds., Basins of the Rio Grande Rift: Structure, Stratigraphy, and Tectonic Setting: Boulder, Colorado, Geological Society of America Special Paper, 291, p. 5-25.

Cooley, S., 2014, Long Profiles (partial), GIS 4 Geomorphology, accessed [April 25, 2014], at URL [http://gis4geomorphology.com/simple-long-profiles/].

Crosby, B.T. and Whipple, K.X., 2006, Knickpoint initiation and distribution within fluvial networks: 236 watfalls in the Waipaoa River, North Island, New Zealand, Geomorphology, v. 82, p. 16-38.

Cys, J.M. and Mazzullo, S.J., 1977, Biothermal submarine cements Laborcita Formation (Permian), Northern Sacramento Mountains, New Mexico, in Pray, L.C., Wilson, J.L., and Toomey, D.F., ed., Geology of the Sacramento Mountains, Otero County, New Mexico: Midland, West Texas Geological Survey, 43-55. 
DuChene, H.R. and Martinez, R., 2000, Post-speleogenetic erosion and its effect on caves in the Guadalupe Mountains, New Mexico and West Texas, Journal of Cave and Karst Studies, v. 62, no. 2, p. 75-79.

Earth Data Analysis Center, 2004, RGIS New Mexico Resources Geographic Information System Program, National Elevation Dataset - Southeast Quarter, accessed [February 1, 2013], at URL [http://rgis.unm.edu/browsedata].

Ehlers, T.A., Armstrong, P.A., and Chapman, D.S., 2001 Normal fault thermal regines and the interpretation of low-temperature thermochronometers, Physics of the Earth and Planetary Interiors, v. 126, p. 179-194.

Ehlers, T.A. and K.A. Farley, 2003, Apatite (U-Th)/He thermochronometry: methods and applications to problems in tectonic and surface processes, Earth and Planetary Science Letters, v. 206, p. 1-14.

Foster, M.A. and Kelsey, H.M., 2012, Knickpoint and knickzone formation and propagation, South Fork Eel River, northern California, Geosphere, v. 8, no. 2, p. 403-416.

Garner, T.W., 1983, Experimental study of knickpoint and longitudinal profile evolution in cohesive, homogenous material, U.S. Geological Society Bulletin, v. 94, no. 5, p. 664-672.

Green, G.N., and Jones, G.E., 1997, The Digital Geologic Map of New Mexico in ARC/INFO Format: U.S. Geological Survey Open-File Report 97-0052. http://mrdata.usgs.gov/geology/state/state.php?state=NM

Hayes, P.T., 1964, Geology of the Guadalupe Mountains, New Mexico, United States Geological Survey, no. 446, 69 p.

Hayes, P.T. and Koogle, R.L., 1958, Geology of the Carlsbad Caverns West quadrangle, New Mexico-Texas: U.S. Geological Survey, Geologic Quadrangle Map GQ-112, scale 1:62,500.

Ingersoll, R.V., 2001, Structural and Stratigraphic Evolution of the Rio Grande Rift, Northern New Mexico and Southern Colorado, International Geology Review, v. 43, no. 10, p. 867-891.

Keller, G.R. and Baldridge, W.S., 1999, The Rio Grande rift: A geologic and geophysical overview, Rocky Mountain Geology, v. 34, no. 1, p. 121-130.

Keller, G.R. and Cather, S.M., 1994, Introduction, in Keller, G.R., and Cather, S.M., eds., Basins of the Rio Grande Rift: Structure, Stratigraphy, and Tectonic Setting: Boulder, Colorado, Geological Society of America Special Paper 291, p. 1-3. 
Kelley, S.A. and Chapin, C.E., 1995, Apatite fission-track thermochronology of Southern Rocky Mountain-Rio Grande Rift-Western High Plains provinces, New Mexico Geological Society Guidebook, 46th Field Conference, p. 87-96.

Kelley, S.A. and Chapin, C.E., 1997, Cooling histories of mountain ranges in the southern Rio Grande rift based on apatite fission-track analysis-a reconnaissance survey, New Mexico Bureau of Mines and Mineral Resources, v. 19, no. 1, 14 p.

King, P.B., 1948, Geology of the Southern Guadalupe Mountains, Texas, U.S. Geological Survey Professional Paper, v. 215, p. 1-183.

King, P.B., 1949, Regional geologic map of parts of Culberson and Hudspeth Counties, Texas: U.S. Geological Survey, Oil and Gas Investigations Map OM-90, scale $1: 150,000$.

Kirby, E. and K. Whipple, 2001, Quantifying differential rock-uplift rates via stream profile analysis, Geology, v. 29, no. 5, p. 415-418.

Landman, R.L. and Flowers, R.M., 2013, (U-Th)/He thermochronologic constraints on the evolution of the northern Rio Grande Rift, Gore Range, Colorado, and implications for rift propagation models, Geosphere, v. 9, no. 1, p. 170-187.

Leonard, E.M., 2002, Geomorphic and tectonic forcing of late Cenozoic warping of the Colorado piedmont, Geology, v. 30, no. 7, p. 595-598.

Maldonado, F., Miggins, D.P., Budhan, J.R., and Spell, T., 2013, Deformation and erosion history for the Abiquiu and contiguous area, north-central New Mexico: Implications for formation of the Abiquiu embayment and a discussion of new geochronological and geochemical analysis, in Hudson, M.R., and Grauch, V.J.S., eds., New Perspectives on Rio Grande Rift Basins: From Tectonics to Groundwater: Geological Society of America Special Paper 494, p. 125-155.

Meesters, A.G.C.A. and Dunai, T.J., 2002, Solving the production-diffusion equation for finite diffusion domains of various shapes Part I. Implications for lowtemperature (U-Th)/He thermochronology, Chemical Geology, no. 186, p. 333344.

Montgomery, D.R. and Brandon, M.T., 2002, Topographic controls on erosion rated in tectonically active mountain ranges, Earth and Planetary Science Letters, v. 201, p. $481-489$

New Mexico Bureau of Geology and Mineral Resources, 2003, Geologic map of New Mexico: New Mexico Bureau of Geology and Mineral Resources, scale 1:500,000. 
Pelletier, J.D., 2004, Estimate of three-dimensional flexural-isostatic response to unloading: Rock uplift due to late Cenozoic glacial erosion in the western United States, Geology, v. 32, no. 2, p. 161-164.

Pray, L.C., 1954, Outline of the stratigraphy and structure of the Sacramento Mountain Escarpment, in Bogart, L.E., Guidebook of Southeastern New Mexico, New Mexico Geological Society $5^{\text {th }}$ Field Conference, p. $92-107$.

Pray, L.C., 1961, Geology of the Sacramento Mountains Escarpment, Otero County, New Mexico: New Mexico Bureau of Mines and Mineral Resources Bulletin 35, scale 1:31,680, 144 p. text.

Pray, L.C., 1977, Stratigraphic and structural features of the Sacramento Mountain Escarpment, New Mexico, in Pray, L.C., et al., eds., Geology of the Sacramento Mountains, Otero County, New Mexico: Midland, West Texas Geological Survey, p. 73-89.

Reiners, P.W. and Brandon, M.T., 2006, Using Thermochronology to Understand Orogenic Erosion, Annual Review of Earth and Planetary Science, v. 34, p. 419466.

Reiners, P.W . and Farley, K.F., 2001, Influence of crystal size on apatite (U-Th)/He thermochronology: an example from the Bighorn Mountains, Wyoming, Earth and Planetary Science Letters, no. 188, p. 413-420.

Reiter, M. and Chamberlin, R.M., 2011, Alternative perspectives of crustal and upper mantle phenomena along the Rio Grande rift, GSA Today, v. 21, no. 2, p. 4-9.

Reiter, M., Shearer, C., and Edwards, C.L., 1978, Geothermal anomalies along the Rio Grande rift in New Mexico, Geology, v. 6, p. 85-88.

Ruhl, K.W. and Hodges, K.V., 2005, The use of detrital mineral cooling ages to evaluate steady state assumptions in active orogens: An example from the central Nepalese Himalaya, Tectonics, v. 24, p. 1-14.

Seidl, M.A., Dietrich, W.E., and Kirchner, J.W., 1994, Longitudinal Profile Development into Bedrock: An Analysis of Hawaiian Channels, The Journal of Geology, v. 102, p. 457-474.

Stock, G.M., Ehlers, T.A., and Farley, K.A., 2006, Where does sediment come from? Quantifying catchment erosion with detrital apatite (U-Th)/He thermochronometry, Geology, v. 34, no. 9, p. 725-728.

Stockli, D.F., 2005, Application of Low-Temperature Thermochronometry to Extensional Tectonic Settings, Reviews in Mineralogy and Geochemistry, v. 58, p. 411-448. 
WoldeGabriel, G., Koning, D.J., Broxton, D., and Warren, R.G., 2013, Chronology of volcanism, tectonics, and sedimentation near the western boundary fault of the Espanola Basin, Rio Grande rift, New Mexico, in Hudson, M.R., and Grauch, V.J.S., eds., New Perspectives on Rio Grande Rift Basins: From Tectonics to Groundwater: Geological Society of America Special Paper 494, p. 221-238.

Wolf, R.A., Farley, K.A., Kass, D.M., 1998, Modeling of the temperature sensitivity of the apatite (U-Th)/He thermochronometer, Chemical Geology , 148, p. 105-114. 


\section{APPENDIX}

\section{BEDROCK AND SEDIMENT DATA}

\section{GMLH1302}

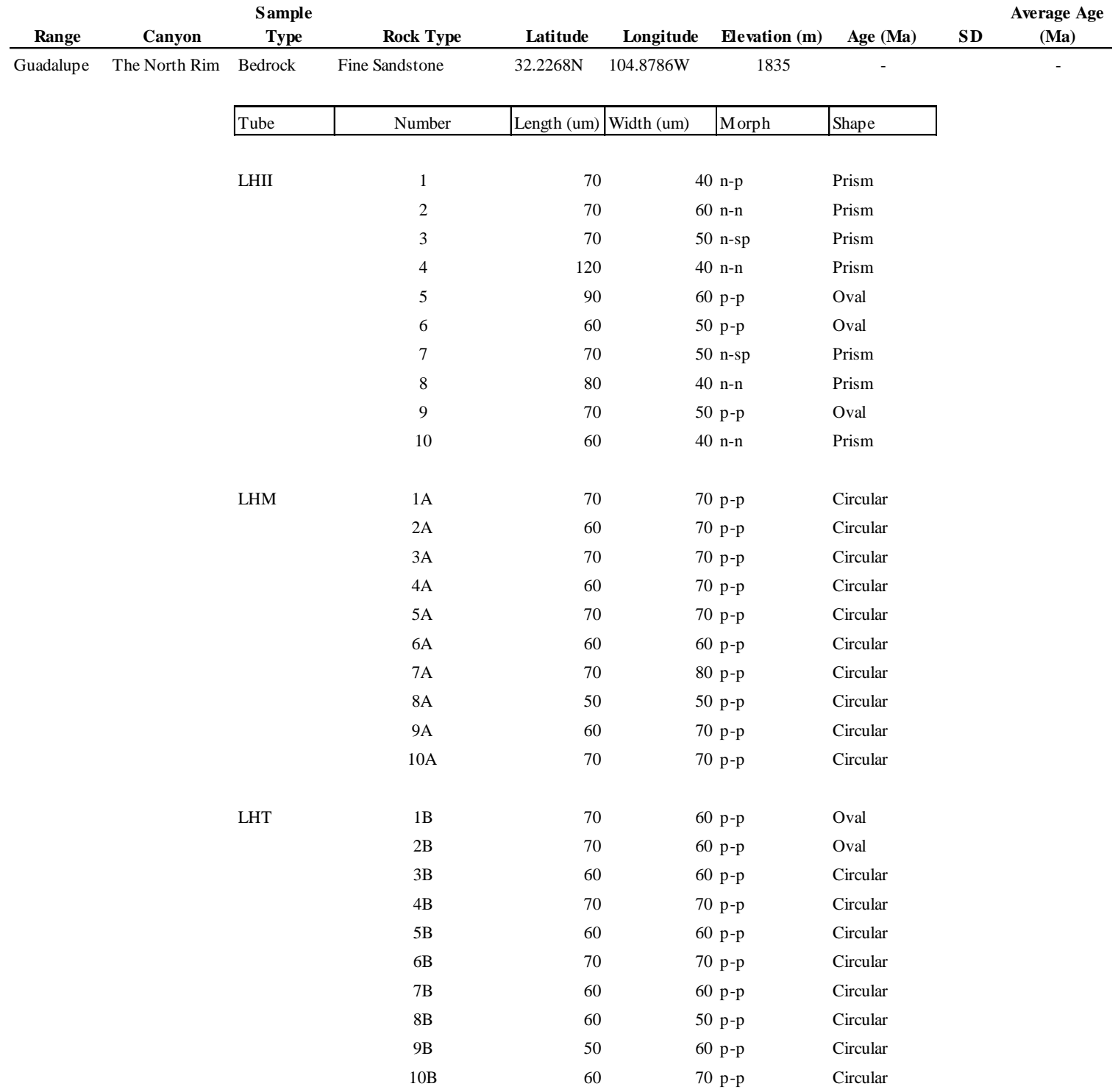




\section{GMLH1305}

\begin{tabular}{|c|c|c|c|c|c|c|c|c|c|}
\hline Range & Canyon & $\begin{array}{c}\text { Sample } \\
\text { Type }\end{array}$ & Rock Type & Latitude & Longitude & Elevation (m) & Age (Ma) & SD & $\begin{array}{c}\text { Average Age } \\
\text { (Ma) }\end{array}$ \\
\hline \multirow[t]{32}{*}{ Guadalupe } & The North Rim & Bedrock & Very Fine Sandstone & $32.2195 \mathrm{~N}$ & $104.8838 \mathrm{~W}$ & 1607 & $17-38.5$ & \pm 10.80 & 28.3 \\
\hline & & Tube & Number & Length (um) & Width (um) & Morph & Shape & & \\
\hline & & LHI & 1 & 100 & & 40 n-p & Prism & & \\
\hline & & & 2 & 100 & & $50 \mathrm{n}-\mathrm{n}$ & Prism & & \\
\hline & & & 3 & 90 & & 40 n-p & Prism & & \\
\hline & & & 4 & 130 & & $50 \mathrm{n}-\mathrm{n}$ & Prism & & \\
\hline & & & 5 & 100 & & $40 \mathrm{n}-\mathrm{n}$ & Prism & & \\
\hline & & LHB & $1 \mathrm{~A}$ & 80 & & $50 \mathrm{n}-\mathrm{n}$ & Prism & & \\
\hline & & & $2 \mathrm{~A}$ & 80 & & $50 \mathrm{n}-\mathrm{n}$ & Prism & & \\
\hline & & & $3 \mathrm{~A}$ & 80 & & $40 \mathrm{p}-\mathrm{p}$ & Prism & & \\
\hline & & & $4 \mathrm{~A}$ & 80 & & 50 n-p & Prism & & \\
\hline & & & $5 \mathrm{~A}$ & 80 & & $40 \mathrm{n}-\mathrm{n}$ & Prism & & \\
\hline & & LHA & $1 \mathrm{~B}$ & 60 & & $60 \mathrm{p}-\mathrm{p}$ & Circular & & \\
\hline & & & $2 \mathrm{~B}$ & 50 & & $50 \mathrm{p}-\mathrm{p}$ & Circular & & \\
\hline & & & $3 \mathrm{~B}$ & 70 & & $60 \mathrm{p}-\mathrm{p}$ & Oval & & \\
\hline & & & 4B & 70 & & 70 p-p & Circular & & \\
\hline & & & $5 \mathrm{~B}$ & 70 & & 70 p-p & Circular & & \\
\hline & & & $6 \mathrm{~B}$ & 50 & & $60 \mathrm{p}-\mathrm{p}$ & Circular & & \\
\hline & & & $7 \mathrm{~B}$ & 70 & & $60 \mathrm{p}-\mathrm{p}$ & Circular & & \\
\hline & & & $8 B$ & 70 & & $60 \mathrm{p}-\mathrm{p}$ & Circular & & \\
\hline & & & $9 \mathrm{~B}$ & 70 & & 70 p-p & Circular & & \\
\hline & & & $10 \mathrm{~B}$ & 70 & & 70 p-p & Circular & & \\
\hline & & LHH & $1 \mathrm{C}$ & 70 & & 70 p-p & Circular & & \\
\hline & & & $2 \mathrm{C}$ & 70 & & 70 p-p & Circular & & \\
\hline & & & $3 C$ & 70 & & 70 p-p & Oval & & \\
\hline & & & $4 \mathrm{C}$ & 80 & & 70 p-p & Oval & & \\
\hline & & & $5 \mathrm{C}$ & 70 & & 70 p-p & Circular & & \\
\hline & & & $6 \mathrm{C}$ & 70 & & 50 p-p & Circular & & \\
\hline & & & $7 \mathrm{C}$ & 70 & & 70 p-p & Circular & & \\
\hline & & & $8 \mathrm{C}$ & 80 & & 70 p-p & Oval & & \\
\hline & & & $9 \mathrm{C}$ & 80 & & 70 p-p & Circular & & \\
\hline & & & $10 \mathrm{C}$ & 70 & & 70 p-p & Circular & & \\
\hline
\end{tabular}




\section{GMLH1318}

\begin{tabular}{|c|c|c|c|c|c|c|c|c|c|}
\hline Range & Canyon & $\begin{array}{c}\text { Sample } \\
\text { Type }\end{array}$ & Rock Type & Latitude & Longitude & Elevation (m) & Age (Ma) & SD & $\begin{array}{c}\text { Average Age } \\
\text { (Ma) }\end{array}$ \\
\hline \multirow[t]{26}{*}{ Sacramento } & Dog Cany on & Bedrock & Red Sandy Siltstone & $32.7827 \mathrm{~N}$ & $105.8376 \mathrm{~W}$ & 2401 & $4.85-6.75$ & \pm 1.34 & 5.8 \\
\hline & & Tube & Number & Length (um) & Width (um) & Morph & Shape & & \\
\hline & & LHE & 1 & 70 & & 30 n-sp & Prism & & \\
\hline & & & 2 & 60 & & $30 n-p$ & Prism & & \\
\hline & & & 3 & 70 & & 30 n-p & Prism & & \\
\hline & & & 4 & 60 & & $40 \mathrm{p}-\mathrm{p}$ & Prism & & \\
\hline & & & 5 & 50 & & 40 p-p & Prism & & \\
\hline & & & 6 & 50 & & 30 n-sp & Prism & & \\
\hline & & & 7 & 50 & & $20 n$-sp & Prism & & \\
\hline & & & 8 & 50 & & $20 \mathrm{n}-\mathrm{n}$ & Prism & & \\
\hline & & LHF & $1 \mathrm{~A}$ & 40 & & 30 p-p & Prism & & \\
\hline & & & $2 \mathrm{~A}$ & 50 & & 30 p-p & Prism & & \\
\hline & & & $3 \mathrm{~A}$ & 50 & & $30 \mathrm{n}-\mathrm{sp}$ & Prism & & \\
\hline & & & $4 \mathrm{~A}$ & 30 & & $30 \mathrm{p}-\mathrm{sp}$ & Prism & & \\
\hline & & & $5 \mathrm{~A}$ & 50 & & $20 \mathrm{n}-\mathrm{sp}$ & Prism & & \\
\hline & & & $6 \mathrm{~A}$ & 50 & & 30 n-p & Prism & & \\
\hline & & & $7 \mathrm{~A}$ & 40 & & $40 \mathrm{n}-\mathrm{p}$ & Prism & & \\
\hline & & & $8 \mathrm{~A}$ & 50 & & $30 \mathrm{n}-\mathrm{n}$ & Prism & & \\
\hline & & LHX & $1 \mathrm{~B}$ & 30 & & $50 \mathrm{p}-\mathrm{p}$ & Circular & & \\
\hline & & & $2 \mathrm{~B}$ & 30 & & $40 \mathrm{n}-\mathrm{p}$ & Circular & & \\
\hline & & & $3 \mathrm{~B}$ & 30 & & $30 \mathrm{p}-\mathrm{p}$ & Circular & & \\
\hline & & & 4B & 50 & & 50 p-p & Circular & & \\
\hline & & & $5 B$ & 30 & & $40 \mathrm{p}-\mathrm{p}$ & Circular & & \\
\hline & & & $6 \mathrm{~B}$ & 30 & & 40 p-p & Circular & & \\
\hline & & & $7 \mathrm{~B}$ & 40 & & 50 p-p & Circular & & \\
\hline & & & $8 B$ & 60 & & 50 p-p & Oval & & \\
\hline
\end{tabular}




\section{GU11}

\begin{tabular}{|c|c|c|c|c|c|c|c|c|c|}
\hline Range & Canyon & $\begin{array}{c}\text { Sample } \\
\text { Type }\end{array}$ & Rock Type & Latitude & Longitude & Elevation (m) & Age (Ma) & SD & $\begin{array}{c}\text { Average Age } \\
\text { (Ma) }\end{array}$ \\
\hline \multirow[t]{33}{*}{ Guadalupe } & Last Chance & Bedrock & Sandstone & $32.2329 \mathrm{~N}$ & $104.6284 \mathrm{~W}$ & 1406 & $23.6-26.7$ & \pm 1.56 & 25 \\
\hline & & Tube & Number & Length (um) & Width (um) & Morph & Shape & & \\
\hline & & LH4 & $1 \mathrm{~A}$ & 80 & & 40 n-p & Prism & & \\
\hline & & LHZ & 1 & 70 & & $60 \mathrm{n}-\mathrm{n}$ & Circular & & \\
\hline & & & 2 & 80 & & 80 p-p & Circular & & \\
\hline & & & 3 & 80 & & 80 p-p & Circular & & \\
\hline & & & 4 & 80 & & 70 p-p & Oval & & \\
\hline & & & 5 & 70 & & 70 p-p & Circular & & \\
\hline & & & 6 & 70 & & 70 p-p & Circular & & \\
\hline & & & 7 & 70 & & 60 p-p & Circular & & \\
\hline & & & 8 & 70 & & 70 p-p & Circular & & \\
\hline & & & 9 & 70 & & $60 \mathrm{p}-\mathrm{p}$ & Circular & & \\
\hline & & & 10 & 70 & & 70 p-p & Circular & & \\
\hline & & LHL & 1B & 80 & & 70 p-p & Oval & & \\
\hline & & & $2 \mathrm{~B}$ & 70 & & 70 p-p & Circular & & \\
\hline & & & 3B & 70 & & 70 p-p & Circular & & \\
\hline & & & $4 \mathrm{~B}$ & 70 & & 70 p-p & Circular & & \\
\hline & & & $5 \mathrm{~B}$ & 70 & & $60 \mathrm{p}-\mathrm{p}$ & Circular & & \\
\hline & & & $6 \mathrm{~B}$ & 70 & & 80 p-p & Circular & & \\
\hline & & & $7 \mathrm{~B}$ & 70 & & 80 p-p & Circular & & \\
\hline & & & $8 \mathrm{~B}$ & 70 & & 70 p-p & Circular & & \\
\hline & & & $9 \mathrm{~B}$ & 70 & & 80 p-p & Circular & & \\
\hline & & & $10 \mathrm{~B}$ & 70 & & 70 n-n & Prism & & \\
\hline & & LHN & $1 \mathrm{C}$ & 70 & & 60 p-p & Oval & & \\
\hline & & & $2 \mathrm{C}$ & 60 & & 80 p-p & Circular & & \\
\hline & & & $3 \mathrm{C}$ & 70 & & 70 p-p & Circular & & \\
\hline & & & $4 \mathrm{C}$ & 70 & & 70 p-p & Circular & & \\
\hline & & & $5 \mathrm{C}$ & 90 & & 80 p-p & Oval & & \\
\hline & & & $6 \mathrm{C}$ & 70 & & 60 p-p & Oval & & \\
\hline & & & $7 \mathrm{C}$ & 80 & & 60 p-p & Oval & & \\
\hline & & & $8 \mathrm{C}$ & 80 & & 70 p-p & Circular & & \\
\hline & & & $9 \mathrm{C}$ & 80 & & 80 p-p & Circular & & \\
\hline & & & $10 \mathrm{C}$ & 80 & & 80 p-p & Circular & & \\
\hline
\end{tabular}


SM2

\begin{tabular}{|c|c|c|c|c|c|c|c|c|c|}
\hline Range & Canyon & $\begin{array}{c}\text { Sample } \\
\text { Type } \\
\end{array}$ & Rock Type & Latitude & Longitude & Elevation (m) & Age (Ma) & SD & $\begin{array}{c}\text { Average Age } \\
\text { (Ma) }\end{array}$ \\
\hline \multirow[t]{16}{*}{ Sacramento } & Dog Cany on & Bedrock & Red Sandstone & $32.7491 \mathrm{~N}$ & $105.9069 \mathrm{~W}$ & 1548 & $20.7-29$ & \pm 5.87 & 24.9 \\
\hline & & Tube & Number & Length (um) & Width (um) & Morph & Shape & & \\
\hline & & LHK & 1 & 50 & & $50 \mathrm{p}-\mathrm{p}$ & Circular & & \\
\hline & & & 2 & 50 & & $50 \mathrm{p}-\mathrm{p}$ & Circular & & \\
\hline & & & 3 & 60 & & $60 \mathrm{p}-\mathrm{p}$ & Oval & & \\
\hline & & & 4 & 60 & & $60 \mathrm{p}-\mathrm{p}$ & Circular & & \\
\hline & & & 5 & 40 & & $50 \mathrm{p}-\mathrm{p}$ & Circular & & \\
\hline & & & 6 & 50 & & $50 \mathrm{p}-\mathrm{p}$ & Circular & & \\
\hline & & & 7 & 60 & & $60 \mathrm{p}-\mathrm{p}$ & Circular & & \\
\hline & & & 8 & 50 & & $40 \mathrm{p}-\mathrm{p}$ & Oval & & \\
\hline & & & 9 & 50 & & 70 p-p & Circular & & \\
\hline & & & 10 & 60 & & $60 \mathrm{p}-\mathrm{p}$ & Circular & & \\
\hline & & LHI & $1 \mathrm{~A}$ & 60 & & $50 \mathrm{p}-\mathrm{p}$ & Oval & & \\
\hline & & & $2 \mathrm{~A}$ & 70 & & $50 \mathrm{n}-\mathrm{sp}$ & Prism & & \\
\hline & & & $3 \mathrm{~A}$ & 70 & & $30 n-p$ & Prism & & \\
\hline & & & $4 \mathrm{~A}$ & 70 & & $60 \mathrm{p}-\mathrm{p}$ & Prism & & \\
\hline
\end{tabular}




\section{GMLH1303}

\begin{tabular}{|c|c|c|c|c|c|c|c|c|c|}
\hline Range & Canyon & $\begin{array}{c}\text { Sample } \\
\text { Type }\end{array}$ & Rock Type & Latitude & Longitude & Elevation (m) & Age (Ma) & SD & $\begin{array}{l}\text { Average Age } \\
\text { (Ma) }\end{array}$ \\
\hline Guadalupe & The North Rim & Stream & Sediment & $32.2232 \mathrm{~N}$ & $104.8841 \mathrm{~W}$ & 1564 & - & & - \\
\hline
\end{tabular}

\begin{tabular}{|c|c|c|c|c|c|c|c|c|c|}
\hline Number & Tube & Length (um) & Width (um) & Morph & Shape & Inclusions & Grade & Color & Shape \\
\hline 1 & 1-GM & 130 & 40 & $\mathrm{p}-\mathrm{p}$ & E & none & A & clear & Prism \\
\hline 2 & 2-GM & 120 & 60 & p-p & $\mathrm{S}$ & none & B & clear & Oval \\
\hline 3 & 3-GM & 40 & 20 & p-sp & E & none & A- & clear & Prism \\
\hline 4 & 4-GM & 90 & 80 & p-p & A & none & C & clear & Circular \\
\hline 5 & 5-GM & 50 & 50 & $\mathrm{p}$-sp & S & none & A- & clear & Prism \\
\hline 6 & 6-GM & 150 & 60 & sp-p & E & none & A- & clear & Prism \\
\hline 7 & 7-GM & 70 & 70 & $\mathrm{p}-\mathrm{p}$ & A & none & C & clear & Circular \\
\hline 8 & 8-GM & 100 & 70 & p-p & S & none & B & clear & Oval \\
\hline 9 & 9-GM & 120 & 70 & p-p & E & none & A- & clear & Oval \\
\hline 10 & 10-GM & 80 & 20 & $p-p$ & E & none & A & clear & Prism \\
\hline 11 & 11-GM & 100 & 40 & p-p & E & none & A & clear & Prism \\
\hline 12 & 12-GM & 90 & 60 & $p-p$ & $S$ & possible & $\mathrm{B}+$ & clear & Prism \\
\hline 13 & 13-GM & 70 & 70 & p-p & E & none & A- & clear & Prism \\
\hline 14 & 14-GM & 100 & 80 & $p-p$ & A & none & $\mathrm{C}$ & clear & Oval \\
\hline 15 & 15-GM & 90 & 60 & sp-sp & E & possible & A- & clear & Prism \\
\hline 16 & 16-GM & 80 & 70 & p-p & S & none & A- & clear & Prism \\
\hline 17 & 17-GM & 110 & 60 & $\mathrm{p}-\mathrm{p}$ & S & none & A- & clear & Oval \\
\hline 18 & 18-GM & 150 & 50 & $\mathrm{p}$-sp & E & none & A- & clear & Prism \\
\hline 19 & 19-GM & 50 & 60 & n-sp & E & none & A & clear & Circular \\
\hline 20 & 20-GM & 70 & 60 & $p-p$ & E & possible & A- & clear & Oval \\
\hline
\end{tabular}




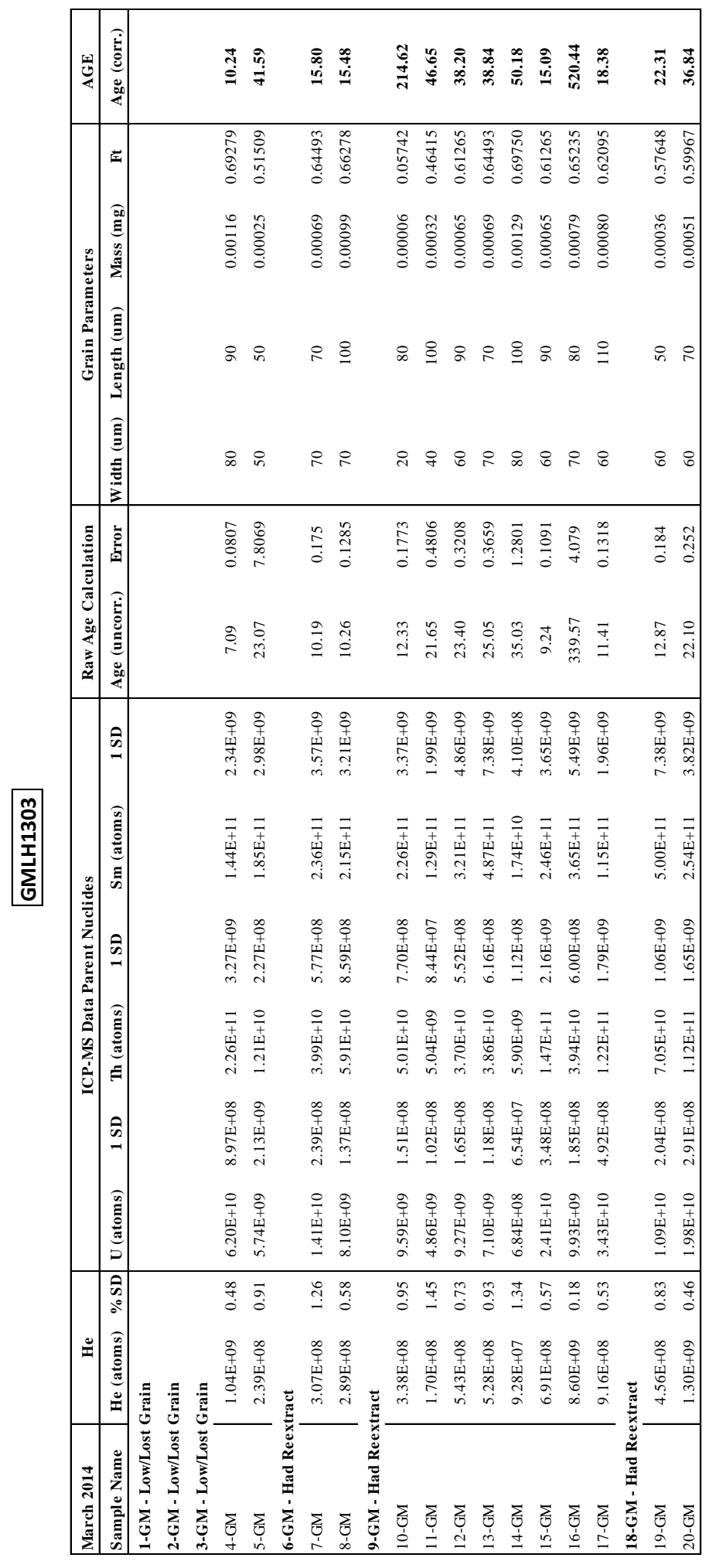




\section{GMLH1317}

\begin{tabular}{|c|c|c|c|c|c|c|c|c|c|}
\hline Range & Canyon & $\begin{array}{c}\text { Sample } \\
\text { Type }\end{array}$ & Rock Type & Latitude & Longitude & Elevation (m) & Age (Ma) & SD & $\begin{array}{l}\text { Average Age } \\
\text { (Ma) }\end{array}$ \\
\hline Sacramento & Dog Cany on & Stream & Sediment & $32.7489 \mathrm{~N}$ & $105.9198 \mathrm{~W}$ & 1313 & - & & - \\
\hline
\end{tabular}

\begin{tabular}{|c|c|c|c|c|c|c|c|c|c|}
\hline Number & Tube & Length (um) & Width (um) & Morph & Shape & Inclusions & Grade & Color & Shape \\
\hline 1 & 1-SM & 110 & 60 & sp-sp & E & none & A & clear & Prism \\
\hline 2 & 2-SM & 120 & 70 & n-n & E & possible & $\mathrm{A}+$ & clear & Prism \\
\hline 3 & 3-SM & 140 & 40 & $\mathrm{p}-\mathrm{p}$ & E & none & A & clear & Prism \\
\hline 4 & 4-SM & 130 & 40 & n-n/sp & E & none & A- & clear & Prism \\
\hline 5 & 5-SM & 110 & 40 & $n-n$ & E & none & A & clear & Prism \\
\hline 6 & 6-SM & 150 & 50 & p-n & E & none & A & clear & Prism \\
\hline 7 & 7-SM & 100 & 50 & n-p & E & possible & A & clear & Prism \\
\hline 8 & 8-SM & 130 & 70 & $n-n$ & E & none & A & clear & Prism \\
\hline 9 & 9-SM & 120 & 80 & p-p & E & possible & A & clear & Prism \\
\hline 10 & 10-SM & 120 & 70 & n-n & E & none & A & clear & Prism \\
\hline 11 & 11-SM & 150 & 50 & n-p & E & none & A & clear & Prism \\
\hline 12 & 12-SM & 90 & 50 & $p-p$ & E & none & A- & clear & Prism \\
\hline 13 & 13-SM & 150 & 70 & n-n & E & possible & A & clear & Prism \\
\hline 14 & 14-SM & 140 & 60 & $p-p$ & E & none & A & clear & Prism \\
\hline 15 & 15-SM & 150 & 50 & $n-p$ & E & none & A & clear & Prism \\
\hline 16 & 16-SM & 150 & 50 & p-sp & E & possible & A- & clear & Prism \\
\hline 17 & 17-SM & 180 & 40 & p-p & E & possible & A & clear & Prism \\
\hline 18 & 18-SM & 140 & 70 & p-p & E & none & A & clear & Prism \\
\hline 19 & 19-SM & 120 & 90 & p-p & E & none & A & clear & Prism \\
\hline 20 & 20-SM & 100 & 60 & p-p & E & none & A & clear & Prism \\
\hline
\end{tabular}




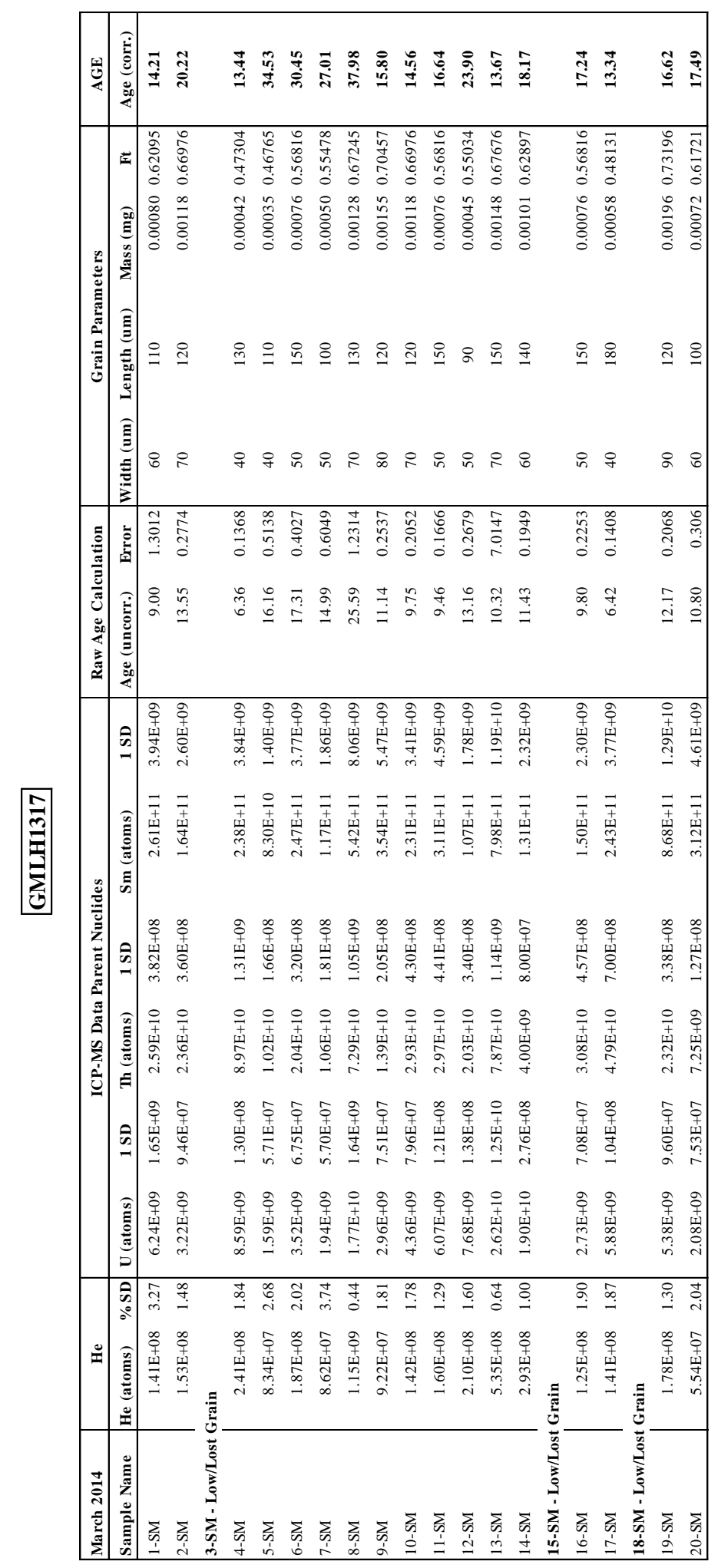

